\title{
The Annals of Chile
}

'If I go down that road basically next stop is Finnegans Wake, and to do that one would always be a kind of tenth-rate Joyce. On the other hand I don't like the idea that there are limits.' Thus, Muldoon comments upon poems in his next volume, The Annals of Chile. ${ }^{1}$ The consideration appears sensible after the explosion of Madoc. A slightly more restrained course can be noticed in the volumes in the aftermath of Madoc. He, nevertheless, retains a remarkable rate of proto-Joycean creativity and metalinguistic scrutiny. 'The word is a suspect device' $(A C, 143)$ runs a self-referential line in the narrathanotography 'Yarrow,' the poetic reaninmation of his mother Brigid who died from cancer in 1974, in a language and a narrative that negate and create themselves continuously towards the end. This confession of linguistic skepticism, 'the suspect device,' vies for attention with such other striking pieces of vocabulary as 'emphysemantiphon,' 'metaphysicattle' (34) and 'oscaraboscarabinry' (35) in 'Cows.' Numeorus other aesthetic interventions beyond logical articulation appear, for example the staccato reiterartion of 'quaquaqua' (20) in 'Incantata;' the inscrutable significance of single letters, for example $S$ - in 'Yarrow;' and the swings of syntax, twists of grammar and turns of poetic form everywhere that testify to the continuous importance of language in Muldoon's poetics. These text samples from Muldoon's seventh and T.S. Eliot-prize-winning volume in 1994 indicate, among other perspectives, the benefit of a post-structuralist distrust of language, Barthesisan ideas of text and jouissance and Joycean word-play to a poetry open to the creative theories of language, as much as to the functions, failures and contexts of language itself. Via deconstructive linguistics and seditious semiotics, Muldoon is often set on slaughtering holy cows and determined to try to present the unpresentable on the poetic canvass. The mystic, mutable and polysemantic figure S - in 'Yarrow' signals with ambivalence a heightened awareness of Parisian post-structuralism on the part of Muldoon: 'she was more into Barthes / than Wolfram von Eschenbach: // largely because of Writing Degree Zero,' 'she leaned over me the way a bow-sprit / (bow-sprit? martingale?) / leans over the water in search of a "referent"' $(A C, 143)$. Such linguistic inquests inherently justify themselves to most writers who take seriously their own art. In The Annals of Chile, the groundbreaking and revelatory approaches to language and poetics appear extremely pertinent to the book's

1 Redmond, 'Interview with Paul Muldoon,' 13. 
themes. An insistent refusal to accept the given of language, and an obsession with the limits and their beyond, parallel the events of death, life and birth that feature so unforgettably in many of these poems.

The Annals of Chile received a lot of critical attention. Inspired by Said and post-colonial theory, Jonathan Bolton shows in 'Irish Stew at the Café du Monde' how the collection's processes of displacement articulate 'the émigré experience' and its 'liberating potential of extranationality, plagued by the lost intimacy of family and friends, and troubled by accusations of national identity.' Indubitably, The Annals of Chile merits such a reading, but its posting of postcolonial concerns from Northern Ireland to the South American continent is also sustained by internal critique of such a paradigmatic interpretation. Furthermore, death, life and birth seem to receive more focused attention in the poems than issues of nationality and post-colonial (which are also clearly present) and frequently Muldoon's neologisms and adlinguistic tendencies tend to disperse and dissipate divisions into the national and the personal.

Tim Kendall gives priority to the personal over the political and argues that 'The Annals of Chile, Muldoon's most elegiac collection to date, is also his most candidly autobiographical. ${ }^{3}$ Clair Wills puts the autobiographical into play by claiming that Muldoon's entire canon is extremely self-referential, and points to its semiotic functions in a Foucauldian manner: 'But paradoxically the wealth of cultural and autobiographical reference doesn't help to ground the poetry. It's almost as though there are too many pointers, and no real way of knowing how to read them.4 Paul Muldoon, in a conversation with Suzan Sherman and Yusef Komunyaka, complicates further the interactions of writing and self. 'I think all writing is autobiographical at some level,' he states, only to counter this claim in the next sentence:

The complete abnegation of the personality, as the language has its own logic and force. I believe in that to a great extent myself. I would argue with what I just said about autobiography, the personality shining through willy-nilly. I think it does, and yet ideally one tries to give oneself over when one writes, to have no sense of self. It's a paradox that there

2 Jonathan Bolton, 'Irish Stew at the Café De Monde,' The South Atlantic Quarterly 64, no. 1 (1999), 48-49.

3 Kendall, Paul Muldoon, 209.

4 Wills, Reading Paul Muldoon, 12. Foucault, 'What Is an Author?' 141-16o. 
must be no sense of self and a complete openness and humility before the language. ${ }^{5}$

In another interview with Ingersoll and Rubin he comments upon the metamorphoses of self: 'But then even that "I"' is something of an invention, as all our 'Is' are 'Adventures of the Letter I,' in Louis Simpson's great phrase. We're all inventions of ourselves at some level. ${ }^{6}$ Muldoon is clearly highly aware of the creative impact of language and letters upon the ever-evolving processes of subjectivity and selfhood.

Guinn Batten argues, using Kristevaen vocabulary, for a psychoanalytical entrance point into The Annals of Chile: 'Psychoanalysis now offers a term for words that emerge from this place of sacrifice and burial: "cryptonomy," the cryptic speech of melancholia that incorporates, and thereby preserves, the dead (and their secrets) even as these ghosts proliferate in homonymic wordplay. ${ }^{7}$ Batten's article shows an acute awareness of the volume's linguistic and political aspects, and defends its referentiality to a speaking subject - no matter how complex this subject might be. The essay is also hostile to 'the postmodern disavowal of origins in a parental space that now seems empty.' A radical approach to The Annals of Chile might suggest that the deferring and differing of linguistic processes render any origin difficult, not only those ruptured by Freudian theories.

Mark Ford ends his insightful review, 'Little Do We Know,' on a curious note: 'The Annals of Chile reveals more clearly than any previous Muldoon collection his awareness of the limitations of that "artificiality"' [Muldoon's conspicuous linguistic cynosure $].^{9}$ This is a curious end line as it suggests alternatives to artificiality in art. What may such alternatives be? Are particular parts or specific types of art more or less artificial than others? Which parts and types? Why? If such distinctions can be easily drawn, alternatives to artificiality nature? authenticity? emotions? human life? - fall outside the arts. Ford's discriminations operate surreptitiously with mimetic criteria that revert to a range of concepts of language as a secondary medium for channeling a priori

5 Suzan Sherman, 'Interview with Paul Muldoon and Yusef Komunyaka,' Bomb, no. 65 (1998), 78.

6 Earl G. Ingersoll and Stan Sanvel Rubin, 'The Invention of the I: A Conversation with Paul Muldoon,' Michigan Quarterly Review 37, no. 1 (1998), 68.

7 Guinn Batten, “He Could Barely Tell One from the Other": The Borderline Disorders of Paul Muldoon's Poetry,' The South Atlantic Quarterly 95, no. 1 (1996), 173.

8 Ibid., 188.

9 Mark Ford, “'Little Do We Know": Review of the Annals of Chile by Paul Muldoon,' London Review of Books 12 January 1995, 19. 
ideas, primordial feelings and the external world, as if it does not make any difference which of the numerous derogatory so-called synonyms you choose when you speak of your beloved and your bereaved relatives. Language is not merely a product of nature, autobiography and authenticity that works through reproduction or reference to 'reality, but also a creative invention with artificial aspects. Explorations and transgressions of language and poetic form ensure liberations, not limitations, and they present in alternative manner the many mysteries of death, birth and life - about which we know so little.

Perhaps we know more of life than we do of birth and death. Muldoon attends to the three dimensions as oppositions, simultaneous events and integral perspectives on existence in remarkable language in The Annals of Chile. What type of language and aesthetic disjuntures may possibly give an account of disintegration and death? What stylistic solutions might be invented to conceive of the unknowable prospects of a new born child? What combinations of creative contrivance can account for the two extremities of human existence in their inescapable daily dimensions? As always, solemn subject matters of human existence do not exclude Muldoon's assiduous aesthetic auditing: artifice and authenticity reflect upon each other. Neither does the poetry constitute undisturbed piety and decorum: irony and contempt intermingle with compassion and intimacy. Muldoon dedicates this collection to his deceased mother, Brigid Regan (1920-1974). A complex commemoration of her, 'Yarrow,' and an exuberant elegy, 'Incantata,' for his former partner, Mary Farl Powers (1948-1992), constitute most of the book. However, a cluster of three poems that celebrates gestation and birth, 'The Sonogram,' 'Footling' and 'The Birth,' occupies a central place alongside the poems of commemoration and mourning. Cryptology captures the mysteries of death and the dead. Vitalogy presents itself as a term for the miracles of birth and the living. If Madoc: A Mystery, perhaps the specimen of encryption and narrathanotology, reads as a centrifuge of endless enigmas, cryptology and vitalogy in The The Annals of Chile function more centripetally to signify vitalism and mortality.

The arrival of new life in for example Virgil's fourth eclogue, in the first chapter of St. John's gospel, Mallarmé's 'Gift of the Poem' or Yeats's 'The Second Coming' also announces the advent of language and of novel forms and new eras. 'The Birth' crosses many lines of language, life and literature in its celebration of Dorothy Aofie Korelitz Muldoon, Muldoon's daughter, in this alphabetic litany. In 'October 1950', a date that probably corresponds with Muldoon's month of conception, the persona attempts to come to terms with the origin and purpose of her or his own life in a manner which imbricates him or her with the contingencies of family life, time, politics and text. But these entry points only reproduce bewilderment: 'Whatever it is, it leaves me in the dark' 
(WBL, 9). 'The Birth' emerges from this occlusion to suggest creative strategies for survival. Together, the twin texts display a shift in human perspective from self-absorbed identity crisis to parental responsibility and the transition between the two poems might be read as a celebration of life despite the unknowability with which it is shrouded. Consequently, the two poems relate to the quandaries of human existence and procreation at a time of conflicting concerns about adoption and artificial insemination, with 'The Birth' also generating the becoming of language and form.

'Seven o'clock. The seventh day of the seventh month of the year' (31). The verses of 'The Birth' begin with a chronological precision and calendrical exacttitude that relate to the temporal imprecision, the father and the possibility of unbirth in the prior puzzlements and allusions to Sterne in 'October 1950': 'Might he have forgotten to wind the clock?' (WBL, 9) 'The Birth' offers certainty and affirmation whereas the previous poem ends on a note of unknowingness and confusion. Muldoon's intratextual allusion to his own poetry and further afield also includes the newborn in ideas of familiarity, tradition and individual talent. The technique also suggests a larger network of associations and creative possibilities into which the baby is born. The birth is unique: economical syntax and lack of a verb mark the inestimable importance of the event: time stands still, nothing else matters. Nevertheless, the alliterative design and the deployment of the sacred number - 7- suggest the power of art to invest the human miracle with order, metaphysical importance and progenital transcendence. 'Dorothy Aoife Korelitz Muldoon.' Undoubtedly, the name, probably unique in the world, refers to Muldoon's own daughter. The girl is inscribed by Yiddish and Irish family tradition. Dorothy stems from Hebrew for 'Gift of God,' and Aoife from the warrior princess of the Land of Shadows who fought single combat with Cúchulainn and gave birth to his son in Irish mythology. The combination of these names - not their singularity - decides her uniqueness, and anticipates her possible futures and possible problems. A metonymical procreativity that attempts to conceptualise the human miracle, to name the unnameable, precedes the baptismal appellation and family address:

realm of apple-blossoms and chanterelles and damsons and eel-spears and foxes and the general hubbub of inkies and jennets and Kickapoos with their lemniscs or peekaboo-quiffs of Russian sable

and tallow-unctuous vernix, into the realm of the widgeon the 'whew' or 'yellow-poll', not 'zuizin' -

Dorothy Aoife Korelitz Muldoon: I watch through floods of tears (31) 
The child is born into an illimitable but alphabetically circumscribed vitalogue of the wonders of language and nature: this metonymity and catalogue of language and life swaddle the infant like a vernix caseosa. Celebrations of vitality and linguistics take place in the first sonnet section before Dorothy Aoife Korelitz Muldoon emerges in the appended quartet: her birth occasions a new stanza to the old sonnet form. The mid-sentence hyphen of the stanzaic severance renders syntactically the umbilical attachment and the abrupt passage of the child into the new world. Biblical ideas of original sin, the covenant and the sorrow of childbirth can be detected in 'floods' and the Caesarian surgery, but alphabetisation, self-dividing idioms and stanzaic configuration of nativity rescue the transcendent moment from traditional religious afflatus, and complicate the unmediated imaginative shaping of natural phenomena in the Romantic tradition. Cerebral comprehension of the emotional situation creates a striking distance from sentimentality. Muldoon also adds vitality and complexity to the unique moment by revitalizing words from the womb of language. 'Gralloch,' Gaelic for 'the viscera of a (dead) deer,' and 'to disembowel' cast midwifery - platonic or medical - in terms of naturalist rawness and the clinical account in the poem of the professional efficiency of the medical personnel imparts rational control as much as the tears indicate poignancy. These words cut clear of emotionalism and retain a stoic composure, a quietude in the face of pain that is developed in the coming to terms with the loss of a new-born child in 'The Stoic' (MSG, p. 37), and that poem's refusal to cultivate traumas of any kind, personal, public or poetic. Metonymic procreativity, self-revelatory techniques of mimetic imperfection and a complex of rational and emotional responses present the wonder of a unique poet trying to come to terms with the miracle of birth. Muldoon also ponders profoundly upon his own poem:

I would have thought that the poem can only be read a little bit ironically. At one end it's a poem about jubilation and the wonderful litany of things in the world. But this random list has resonances with some of the things I'm interested in - it's as if this world into which the child is going to arrive is somehow one's own world and that's dubious perhaps. ... But it's not as if I'm interested in sending people to dictionaries or anything. These are absolutely the right words in the right order. But that phrase does draw attention to itself. ${ }^{10}$

10 Redmond, 'Interview with Paul Muldoon,' 12. 
Language-conscious, heteroglossic, versatile and divided in form: the stanziac invagination in 'The Birth' adds new form and life to this birth poem, as do the multiple terms of biology, obstetrics, geography, mythology - quiffs of language - revitalised, current, with shrieks of energy, and with a life inside or outside the Oxford English Dictionary. This vocabulary and amazement also evoke Gerard Manley Hopkins' celebrations of the wonders of God's creation, the biomorphic unities of Dylan Thomas and several Muldonic favorites: mycology, hippology, dialectology, terminology and interpoeticality with Heaney. The final verses indicate a postnatal suture - probably to stitch a Caesarean gap as the child enters its new world feet first. The stanza captures a moment of menace and wonder, the risks of everything that might go wrong during a complex birth. This situation of labour and delivery is also, as any poet will know, a process of artistic work and birth of poems. Muldoon's many years of creative labour and poetic delivery enable him to articulate in new language and novel form the worries and wonders of the magic moment of a child's birth. Frequently, Muldoon sets his feet first, as opposed to free verse and L-AN-G-U-A-G-E poetry.11

'The Birth' also delivers the semiotics of the two preceding poems, 'The Sonogram' and 'Footling. 'The Sonogram' consists of an octave in which a second foetal scan that images the hand and thumb of the unborn child as 'a woman hitching a ride; / a gladiator in his net, passing judgment on the crowd,' complements a prior scan that resembles 'nothing so much / as a satellite map of Ireland' (29). The foetal limbs function as an index of unusual transport, historical events and geographical destination. Technically, the movements of these verses present a departure from literary tropes and national and paternal identities to an invincible individuality that liberates itself from ancient rituals. The scanning enacts imaginative and prosodic liberty as much as the unwritten future of the unborn child. In the succeeding sonnet, 'Footling,' 'she's now got cold feet / and turned in on herself, the phantom "a" in Cesarian' (30). The child's prenatal scorn of the world plays on a prioritisation of selfcontained poetics - metrical feet, phantom letters, silence, the caesura and alphabetic introversion - in poetic delivery and the Caesarean violence enacts

11 For all his admiration for Eliot and for all his overlapping interest with L-A-N-G-U-A-G-E poetry, Muldoon's poetry always derives and deviates from a strong sense of foot, metre and form. For some of the ideas and motions of language poetry, see Bruce Andrews and Charles Bernstein, The $L=A=N=G=U=A=G=E$ Book (Carbondale: Southern Illinois University Press, 1984). 
how the life of a poem is sometimes violently extracted from its protected domain into an unrestrained world of writing and social environment. ${ }^{12}$

New life, new birth, passing on: Yeats's view of a future - private, national and global - in 'A Prayer for My Daughter' and 'The Second Coming' was shadowed by the ideological gloom and historical events of his own time. Muldoon's 'The Birth' evolves from his own lines of poetry and paternity that invaginate private relations and public issues. Where the narrathanotographic terror tale 'The More a Man Has the More a Man Wants' in Quoof and the parapostmodernist beast Madoc inscribe their own annihilation of literature and life by way of a Derridean advancement of the future as an unpredictable monstrosity, 'The Birth' conceptualises continuance and the positive possibilities of unknown futures. While the deconstructive aesthetics of Quoof, Madoc and earlier interacts interacts with the civic chaos of hunger strikes, hardline Thatcherism and paramilitary upheaval, The Annals of Chile coincides with the tentative ceasefires. In a time of possible peace and constitutional reform, the secluded privacy of 'The Birth' is in step with the nascent optimism of a new era in Northern Irish history, and with its literary inscriptions. Frank Ormsby's The Ghost Train - 'peace is the way you settle in our arms' - and Deidre Madden's One by One in the Darkness also align the worries and wonders of pregnancy and childbirth with the uncertainties and hopes of a peace process in Northern Ireland. ${ }^{13}$ In comparison to these provisional sketches of individual and social uncertainties, Heaney - still grand master of memory and metrics has recourse to overt religious and literary templates in his volume of retrospection in 2001, Electric Light. Procreation in 'Out of the Bag' is firmly couched in the terms of nostalgia of childhood and religious rituals, and his resuscitation of Virgil's encomiastic birth poem 'Eclogue IV' nods belatedly to the new

12 Muldonic intricacies of this kind are multiple. This quip on ceasarean and caesura extends in The Annals of Chile to 'César Vallejo: Testimony' (32), 'the unvoiced "c" in Connecticut' (139) and the ironic intrusion, '(note the caesura)' (64), which, of course, fills in the gap to which it draws attention. Leaps of language, logic, time and space, frequently indicted by the sign $\S$, characterise Muldonic technique and imagination, and mark most poems in this collection. Lawrence Norfolk comments on 'The More a Man Has the More a Man Wants' 'that any paraphrase would need to distinguish more varieties of caesura than the Inuit supposedly do snow.' 'The Abundant Braes of Yarrow,' The Times Literary Supplement, 21 August 1994, 32. Similar sound distinctions and disappearances in other volumes include: 'So long as there's an "if" in California,' (WBL, 39); 'Paul? Was it you put the pol in polygamy,' (Mad, 6); 'You can take the man out of Armagh but, you may ask yourself / can you take the Armagh out of the man in the big Armani suit?' ( $H, 43)$; 'an orgasm, you see, sir, or a seizure' $(H, 49)$; 'there's an Auden in every Audenauer', $(H, 105)$.

13 Frank Ormsby, The Ghost Train (Loughcrew: The Gallery Press, 1995), 51; Deirdre Madden, One by One in Darkness (London: Faber and Faber, 1997). 
pragmatic politics in the North and the conditions that would lead to the Good Friday Agreement of 1998, while also bestowing an accolade upon the victor (whoever that might be). Despite the artistic grandeur of Electric Light, Heaney had proceeded from controversial sedition in Northern Ireland via visionary frames of reference to the status of an Amnesty International laureate. ${ }^{14}$ In 1994, Muldoon's 'The Birth' sustains much of its visionary power in its privacy and in its eschewal of the political pressures that nevertheless provide one of the many frames to the poem. Muldoon's 'The Birth' contributes to a tendency in the writing of Northern Ireland in the 1990s that moved beyond old concepts of Mother Ireland to new imaginings and new possibilities; in language, in literature and in identity and national future.

The belle-lettristic and aurally-shaped poetic triplet of 'The Sonogram,' 'Footling' and 'The Birth' manifests the arrival of a premeditated linguistic aestheticism. Neologisms, a copious variety of registers, misprisions and seemingly semiotic inapprehensiveness mediate the wonders of birth and life amidst the uncertainties and finitudes of the human existence. Too obviously, perhaps, the conception, gestation and delivery of the child in these poems also play on a structuralist view of the inescapable formativeness of language and the motions of generative grammar. Muldoon's acts of metametonomy and alphagendering, however, revel as much in Derridean ideas of writing, iteration and context as in the possibilities of poetics and linguistics liberated by performative linguistics and Jakobsonian analyses.

In their exposure of private life these textual triplets reveal a naked Muldoon; the author disentangles himself from his previous nexus of paronomasia and homonymic forms, especially in Mules. His subjective correlatives here flow in a more intimate and personal vein. However, this aspect brings into view new characteristics of Muldoon as a vulnerable and collaborative partner and parent: more accessible, parental, poignant and even lachrymose, and less encoded, rebellious, ironic and callous. These texts also belong to a large family of ancestral literature and contemporary writing, and foster new images of a Northern Ireland in the transition from the death of war to the inception of peace. All the same, his alphabetical formations, metrical cohesion and formal assuredness keep in check profuse emotionalism and communal commitment, and resist an unmediated referentiality. As much as an autobiographical account or public metaphor, 'The Birth,' 'Footling' and 'The Sonogram' co-exist

14 For an analysis of Heaney's Electric Light, see Ruben Moi, “The Cure of Poetry That Cannot Be Coerced": Text, Canon and Context in Seamus Heaney's Electric Light', in New Perspectives on Seamus Heaney, edited by Bland Crowder and Jason Hall (Madison: University of Wisconsin Press, 2007), 172-189. 
as alphagrams of lingual engendering and human procreativity. They evince how deconstructed concepts of language, author and context produce a text of alphabetic conceit, aesthetic élan, autobiographical explicitness and contextual consequence. Perhaps the shifts from organicist to alphabetic poetics, from metonymy to metametonymy, from structuralist to deconstructive linguistics ensure for posterity the lives of the poems, their author and their subject. Perhaps the many alignments of human procreativity with the theories of language will come to mark the end of the century Rorty found, already in 1967, to be characterised by the linguistic turn, a turn Muldoon exhausted in Madoc. $^{15}$

This poetic trinity, with its subject matter of Dorothy Aofie Korelitz Muldoon, its alphabetic revelations and its stanzaic strategy, embodies most of the concerns and creativity of The Annals of Chile. From A to Z, from beginning to end, from alpha to omega, The Annals of Chile is enlivened by a gynocentric universe of engendered forms, alphabetic evolutions and polycentric lines of identity. For example: Muldoon opens The Annals of Chile with a translation of the myth of Leto from Ovid's Metamorphoses, Book vi. The passage erects a textual scaffolding for the volume's geographical, identitarian, poetic and public indeterminacies. Classical accounts of the misogynist persecutions of a female demiurge intersect with spite, hatred and vengeance in Northern Ireland, and conduct a dialogue with Heaney's poetry. The template, Metamorphoses, above all, captures the mutations and transformations of language itself as a state both separate from and spliced with its subject matter and contextual concerns, the type of Muldonic tranceformation set up by 'Trance' and Mules. ${ }^{16}$

Births, transitions and tranceformations of language, lines and location charge the whole volume with vital novelty and the matrilinealty of language, family and nation from the triplet of birth poems also inhere in 'Brazil.' This text presents Oedipal relations between child and mother, a pool of undifferentiated desire that also effects geo-linguistic orientations: 'if not Brazil, then Uruguay,' 'if not Uruguay, then Ecuador' (6). The chain of displacements destabilises the geographic certainty of the title, and desublimates the urge for an idealised location in the mythology of Hy Breasil. Illicit attraction to the mother and linguistic dispersion end with the appearance of a paternal figure:

\footnotetext{
15 Richard Rorty, The Linguistic Turn: Recent Essays in Philosophical Method (Chicago: University of Chicago Press, 1967).

16 See the analysis of 'Trance' and Mules on pages $\mathrm{xx}-\mathrm{xx}$. For an analytical survey of Ovidian templates in contemporary Northern Irish poetry, see John Kerrigan, 'Ulster Ovids,' in The Chosen Ground, ed. Neil Corcoran (Bridgend: Poetry Wales Press, 1992), 237-270.
} 
'There is inherent vice

in everything,' as O'Higgins

would proclaim: it was O'Higgins who duly

had the terms 'widdershins'

and 'deasil' expunged from the annals of Chile. (7)

O'Higgins, a man of Irish descent who contributed to the liberation of Chile, also acted as a linguistic censor (at least in Muldoon's poem) by expunging the English word for anti-clockwise and the Irish word for clockwise. Muldoon's reinsertion of the terms constitutes an act of linguistic authority and indicates a word-right beyond censure. 'Oscar', the communications code for the letter $\mathrm{O}$ (which is almost indistinguishable from the digit for nothing, o), functions in its supplicatory evocation of disfiguration as a vehicle for semantic transport. As much as nominating a number of famous figures of indeterminable identity, the proper name is already marked by alphabetic iteration and paronomasia. Writing marks identity with sameness, alterities and alternatives. Remarkably, this poem anticipates some, but not only, tragic fates. The heroic death in single combat of Oscar, Gaelic for deer-lover, ended the Fenian cycle. fate and the love of animals appear with macabre feminism in this post-mortem battle:

my mother's skeleton

has managed to worm

its way back on top of the old man's, and she once again has him under her thumb. (8-9)

In the contexts of this book, the grave scene is both autobibliographical and autobiographical: Old Mother Ireland never will succumb, parental differences from 'The Mixed Marriage' $(M, 42)$ and numerous previous poems are not put to rest, Muldoon's elegies for his parents are prodigious. This posthumous gender combat appears as the final denouement after two scenes of domestic amorousness and dramatic disappearance. In view of these transformation scenes, with their visual qualities and melodramatic morbidity, the title hands out its own Oscar for cinematic techniques, and recalls the histrionics and tragedy of Wilde, whose heroic name he received from his mother - the nineteenth century Irish nationalist and mythographer Lady Jane Francesca Wilde turned out to be dismally prophetic. In the domestic scene of the poem Oscar also denotes the family dog that 'lies between us like an ancient quoof': the 
incestuous pedigree of Muldoonian linguistics deviates from dictionaries, etymologies and ordinary proprieties. In its many disfigurations of prominent men, 'Oscar' also extends to Terry Eagleton's Saint Oscar. Written for Field Day and denounced by Edna Longley as 'axes, tears and cheap epigrams,' the play is one of the many texts appropriated by the customary ideological divisions of culture in Northern Ireland. ${ }^{17}$ 'Oscaraboscarabinary', states the later poem 'Cows' (33). The disfigurations of 'Oscar' unmake ideas of transparent language, simplistic identitarian referentiality and the too frequent binary delineations of culture in Northern Ireland.

'Oscar' indicates, among many other things, a dog's life, 'Cows' something else. This poem is dedicated to the Belfast painter Dermot Seymor, whose paintings cover the book jackets of The Annals of Chile and of Muldoon's 1995 play, Six Honest Serving Men. The superlinguistic characteristics of the poem, however, tend to eclipse the ekphrastic frame of reference. Cows - not dogs, cattle or oxen - engender matrilineal lines through an emphasis on forms of femaleness and domesticity that stand opposed to the other collective names for the beast that stress property and production. The audacity of juxtaposing women to not entirely complimentary creatures of nature revivifies the slanted gynocentrism of Mules and the many feminine beasts of Quoof, not least the chauvinist herding of cows in 'Cherish the Ladies.' The chauvinist herding includes branding and sardonic humour: 'Had Hawthorne been a Gael, / I insist, the scarlet "A" on Hester Prynne / would have stood for alcohol' (33). The ironic quip imprints alphabetic significance upon the poem and signifies cultural stigmatisation as being among the poem's discourses. A cattle truck in contentious borderlands - Northern/Irish more than South-American - transposes mythological cattle raids and silk of the kine symbolism to contemporary controversies, and illustrates the poem's many crossings. The freight carrier becomes a vehicle for hidden meanings and semantic motoring as much as for the smuggling of illicit merchandise. 'Cattle' still evokes the border campaigns and armed raids of epic tales, such as Táin Bó Cúailnge, The Cattle Raid of Cooley. During the recent war in Northern Ireland cattle trucks were as likely to smuggle microwaves, hi-fis, arms, petrol and alcohol as to transport livestock. ${ }^{18}$ Obsolete Old English for royal and rare for cine, outmoded and philological significations of kine (cows) remain present in the poem's Republican resonances and cinematic techniques: 'Again the flash. Again the fade.' In the sense

17 Terry Eagleton, Saint Oscar (Derry: Field Day, 1989); Longley, The Living Stream: Literature and Revisionism in Ireland, 29.

18 See Thomas Kinsella's translation and Louis Brocquy's illustration of the old epic: The Táin (Oxford: Oxford University Press, 1970). 
of the gestures of non-vocal communication, kine fits the smugglers' silence and all the codes of Northern Irish interactions in a poetic heterologics reminiscent of 'The Radio Horse' from New Weather (21). Such translations meet with the neologendering of the bovine: 'Emphysemantiphon of cows,' 'no Devon cow-coterie,' 'the metaphysicattle of Japan,' 'some oscaraboscarabinary bevy of cattle' overrun the elaborate etymology of 'boreen' - Gaelic for cow path and reminiscent of the mode of (Heaney's) place-name poems. The whole poem, this one too you might say, puts Muldoon's denial of interest 'in sending people to dictionaries or anything' into a peculiar light. ${ }^{19}$ Linguistic cowplay meets with ekphrasis: 'Cows' verbalises Seymour's visual catalogue of cows, and his surreal The Russians Will Water Their Horses on the Shores of Lough Neagh. Do Muldoon's 387 words say more than Seymor's painting? The challenge is certainly there, and perhaps they do in their mind-provoking language and concerns. Finally, the poem apparently explodes codification and frames:

Now let us talk of slaughter and the slain, the helicopter gun-ship, the mighty Kalashnikov: let's rest for a while in a place where a cow has lain. (35)

The Russian Kalashnikov, the most popular assault rifle in the world also known as the AK-47, connects the state in the poem with paranoia, the Cold War 'red scare' mindset and guerilla warfare in so many other corners on the globe. The anxieties are also of the artistic kind. The 'talk of the slaughter and the slain' disposes with conversation of language and literature in the poem and the final line can be read as an obvious misprision of Yeats's 'Memory' which highlights the manner in which Muldoon's verse preserves and perverts Yeats's lyrical commemoration of forgetfulness. These anxieties are also suffused with the fright and fear of the couple on the run from or to the Volkswagen in the borderlands in 'Ireland' (WBL, 19). Furthermore, the final lines relate uneasily to the many states, orders and discourses in 'Pancho Villa' ( $M, 11-13)$. In a manner echoing the unsettled admonitions in 'Pancho Villa,' parts of the conclusion in 'Cows' command an uncoded explicitness that the rest of the poem avoids: direct calls for committed poetry which adopts an iconography of army presence and paramilitary activity in Northern Ireland and other war zones, and provides some poetic comfort and consolation. But this explicitness is nothing but a statement that is alarmingly unconscious of, or deliberately conceals, its own codifications. Arguably, an unmediated artistic engagement with violence indulgence, trauma cultivation and war poetry only

19 Redmond, 'Interview with Paul Muldoon,' 12. 
prolongs in imagination geo-socio-political schismogenesis and entails simplistic deployment of language. Recourse to colloquialisms - 'talk of slaughter and the slain' - confirms communal lingo and monomindedness. A mere reproduction of an infallible and calcified language of referentiality and communication predetermines recognition of the established more than it presents cognitions of the emergent. Facile pastoralism evokes the pleasantries of past oral traditions and fables, and pays lip service to those who will not see or listen or go beyond their own world view. As such, the final lines do not conclude, they constitute another statement that requires decoding in the overlapping systems of significations. The balancing of coded language and explicit rhetoric is a well-known phenomenon in the many discourses commonly found in more politically-charged social environments. Such contestation of competing styles, registers and rhythms is standard to the dynamics of literature too, as Bakhtin demonstrates so forcefully, and Muldoon enacts with such conceit. ${ }^{20}$

"Paul? Was it you put the pol in polygamy," runs the alliterative and punning New York poetry scene query in the acrostic poem 'Capercaillies' (6). Whatever the answer is, it seems certain that Muldoon has certainly contributed to a lot of other polies. His creativity with language - the copulation of Gaelic and English, the many neologisms, the revitalisation of old words, the numerous attempts to penetrate or violate the $\mathrm{OED}$, the consistent engendering of conceit, the spurts of irreverent and irreconcilable semantics, his intimate relations to Yeats and Heaney and numerous other poets, his autoreferentiality, his ambivalent intercourse with post-structuralist concepts of language, his frequent outrageous polytextuality - gives shape, significance and salt to his many birth poems and vitalalistic verses at a time of transitions in the poetics of Northern Ireland and elsewhere, and in the societies with which The Annals of Chile interacts most closely.

The birth poems might be the most novel and propitious in The Annals of Chile, but an elegiac tone, nevertheless, prevails in the volume. Whereas the vitalogy of the birth poems stems from the miracles of human anatomy and procreation, many poems in this book, for example 'Milkweed and Monrach,' 'Incantata' and 'Yarrow' derive their cryptology from death and mourning. The entire book is dedicated to Muldoon's mother. She dwells in the maternal and feminine aspects of the volume even though direct reference is continually deferred. Leto in the opening revivification of 'Ovid: Metamorphoses,' the mother in 'Brazil,' the wife in 'Oscar,' motherhood in the birth poems, femaleness in 'Cows,' partnership in 'Incantata' and associations of Mother Mary and

20 Mikhail Bakhtin, The Dialogic Imagination, trans. Caryl Emerson and Michael Holquist (Austin: University of Texas Press, 2004). 
Mother Ireland contribute to the complex commemoration of Muldoon's mother, a commemoration that eschews wholesome encomium, a commemoration that questions, probes, refracts, continues.

Philosophers have grappled with the concerns of death and commemoration from Plato's Phaido to Derrida's The Work of Mourning and Cicero states in his fifth philippic that 'the life of the dead consists in the recollection cherished of them by the living.'21 The canon of poetry's immemorial office to lament the dead includes in modern times Milton's 'Lycidas' for King, Gray's 'Elegy Written in a Country Church Yard,' Shelley's 'Adonais' for Keats, Whitman's 'When Lilacs Last in the Dooryard Bloom'd,' Tennyson's 'In Memoriam A.H.H.' for Arthur Henry Hallam, Eileen O'Connel's 'Lament for Art O'Leary' for her husband and W.H. Auden's 'In Memory of W.B. Yeats.' Elegies hold a central place in Yeats's verses: 'In Memory of Major Robert Gregory,' ‘Sixteen Dead Men,' 'Parnell's Funeral,' 'The Municipal Gallery Revisited,' 'Under Ben Bulben.' Michael Longley, Derek Mahon, Medbh McGuckian and Ciaran Carson's poetry include elegies and laments; Northern Ireland was a place of death and mourning during The Troubles. Heaney's oeuvre is replete with elegies for victims of the Troubles, for his family and for his fellow artists and poets in such poems as 'Elegy for a Still-born Child,' 'The Strand at Lough Beg' for his murdered cousin Colum McCartney, 'Casualty' for his friend Louis O’Neill, 'In Memoriam Seán Ó Riada' for the famous composer, 'In Memoriam Francis Ledwidge for the Irish poet, 'Clearances' for his mother, 'On His Work in the English Tongue' and 'Stern' for Ted Hughes, 'Audenesque' and 'The Hug' for Joseph Brodsky, 'Out of this World' for his fellow Polish poet and 1980 Polish Nobel laureate Czesław Miłosz, 'Death of a Painter' and 'Loughanure' for painters Nancy Wynne Jones and Colin Middleton and 'The door was opened and the house was dark' for singer David Hammond. ${ }^{22}$ Joyce's 'The Dead,' which Muldoon makes the omphalos of his creative-critical abecedarium of the acknowledged and the arcane in Irish literature, To Ireland, I, together with Yeats's 'Easter 1916,' still tend to occupy the centre of the canon of commemoration in Ireland and beyond.

The preservation of the memory of the many subjects of these elegies is perpetuated by their ebalmment in linguistically innovative language, and via

21 Cicero, The Orations of Marcus Tullius Cicero, trans. C.D. Younge, vol. 4 (The Project Gutenberg Ebook: The Project Gutenberg Ebook, [43 BC] 2004).

22 For further reading on elegies, see Jahan Ramazani, Yeats \& the Poetry of Death: Elegy, SelfElegy, and the Sublime (New Haven: Yale University Press, 1990); Poetry of Mourning: The Modern Elegy from Hardy to Heaney (Chicago: University of Chicago Press, 1994); Matthew Campbell, 'Muldoon's Remains,' in Paul Muldoon: Critical Essays, ed. Tim Kendall and Peter McDonald (Liverpool: Liverpool University Press, 2004), 170-188; Clair Wills, 'Muldoon and the Dead,' in Paul Muldoon, ed. Elmer Kennedy-Andrews (Gerrards Cross: Colin Smythe Limited, 2006), 189-199. 
a creative prosodic mastery and renewal of literary form: this aesthetic novelty honours the subject's uniqueness and perpetuates the life and death of the deceased in the memory of the living. In the longer lines of life and literature, Wordsworth, for example, complains of inadequate language in Thomas Grey's dirge 'Sonnet on the Death of Mr Richard West, 1742' in Lyrical Ballads, and laments the 'sad incompetence of human speech' in the face of natural grandeur and imagination in The Prelude. ${ }^{23}$ Poetry's challenge to represent the unpresentable reaches an apogee in attempts to apprehend the sublime and the metaphysical dimensions of the human existence in the stern face of loss and death. Muldoon inserts himself vigorously into the tradition of recollecting the dead. Enigmatic linguistics, coded forms and anguished attempts to utter the unutterable prolong the lives of the deceased in the memory of those who mourn them. Muldoon's poetry, like his literary creativity in To Ireland, I, crosses the many subtleties of the old and the new in life, death, literature. The breaking of language, prosody and form discloses new insight, new rhythms, new formations of how we live and think in respect to the dead and gone. Muldoon's elegies are Muldoonesque: the vital and boundless language of the birth poems is in many ways infused into the laments.

'Incantata' recreates the art and life of Mary Farl Powers (1948-1992), and the relationship between her and Muldoon in the early 1980s. 'Yarrow' commemorates Muldoon's mother Brigid Reagan (1920-1974). 'Milkweed and Monarch' meditates upon the passing away of his mother and father, Patrick Muldoon (1910-1985). Elegies and commemorations run consistently and creatively throughout Muldoon's poetry. The dedication in New Weather, his debut collection from 1973, states 'for my Fathers and Mothers,' in what Kendall terms a 'polycentric pedigree' for a volume that includes 'The Waking Father', the proleptic lamentation of paternal death. ${ }^{24}$ It is noticeable that the dedication in New Weather gives priority to the father. Muldoon's father appears at an earlier point and more continuously throughout the poetry than his mother. Elegies and commemorations of his father(s) include the fine and surreal elegies 'The Fox,' 'Brock' and 'The Coney' (мтв, 3, 12, 24), the cryptic 'The Mirror' (Q, 2-13), the poetic meditations on the origins and absence of a father in 'Immrama' and 'Immram' (WBL, 23, 38-48). Muldoon's speculations on an alternative life of a father and the unbirth of the son in 'The Bangle (Slight Return)' in the next volume Hay (109-140) also deal with aspects of his father(s). Additionally, the entire volume Meeting the British is written 'In memory of Patrick Muldoon

23 William Wordsworth, Lyrical Ballads (Oxford: Oxford University Press, [1789] 1985), 162; Wiliam Wordsworth, The Prelude (New York: W.W. Norton, [1850] 1979), 599.

24 Kendall, Paul Muldoon, 23. 
1910-1985' and shades of and references to father figures ghost many other poems. A range of other verses includes memories of a living father. ${ }^{25}$ Conversely, poems about his deceased mother(s) are fewer and further between, although she too appears as a live person in some earlier poems, for example ' $\mathrm{Ma}$ ' and 'The Mixed Marriage' $(M, 23,42)$. This distance to mothers, the female and the feminine is also noticeable in the later dead-pan quip in the aptly - entitled 'Errata:' "For "mother" read "other"' $(H, 88)$. The persona's mistaking of 'his mother's name, "Regan", for "Anger"' also expresses ambivalent relations to his mother in this volume's 'Milkweed and Monarch', an elegy for his father and mother in which 'he could barely tell one from the other' (10-11). Previous and later elegies for family and friends range from 'My Grandfather's Wake' (м тв, 5), 'Turkey Buzzards' for his sister Maureen $(H L, 78-82)$, 'The Soap' for his friend and ввС colleague Michael Heffernan (мтв, 25-29), 'Sillyhow Stride' for friend and rock musician Warren Zevon $\left(H L, 95^{-107)}\right.$ to 'Cuthbert and the Otters' (otTwK, 3-13) in memory of Seamus Heaney. Commemorations of other writers, both living and dead, in all sorts of manners, from the directly referential to the cryptic and coded, require another book. ${ }^{26}$ The elegiac stance dominates this volume. 'Incantata' mourns the death of Mary Farl Powers, renowned artist and Muldoon's former partner and 'Milkweed and Monarch' attends to the loss of his father and mother. The Annals of Chile is, however, written 'In Memory of Brigid Reegan (1920-1974) and Muldoon's elegy for his mother takes up more than three quarters of the entire book.

'Milkweed and Monarch,' judged by its contents in a volume dominated by elegies dedicated to his mother, is most certainly a tribute to Muldoon's parents, but, in typical Muldoonesque manner, it is unusual, bewildering and wide-ranging. This poem links directly up with the combat of parental skeletons in the previous poem, 'Oscar,' in which the mother's skeleton 'has managed to worm / its way back on top of the old man's / and she once again has him under her thumb' (9). In many ways 'Milkweed and Monarch' also continues the commemoration 'for my mothers and fathers,' 'the polycentric pedigrees,' from New Weather. ${ }^{27}$ This time around, both parents are remembered in

25 For a wider view on fathers and the importance of the past in Muldoon's and Northern Irish poetry at the time, see Edna Longley, "When Did You Last See Your Father?" Preoccupations of the Past in Northern Irish Writing 1965-1985,' in The Living Stream:Literature and Revisionism in Ireland, 150-173.

26 Muldoon's references range from the accessible to the arcane. They can be best traced in his own creative criticism, in To Ireland, I and The End of the Poem.

27 The first page caption of New Weather states 'for my Fathers and Mothers' and Kendall terms this a 'polycentric pedigree.' Kendall, Paul Muldoon, 23. 
a single poem of as much paradox and ambivalence as compassion and grief. The choice of the villanelle form links these elegiac verses with such predecessors as Dylan Thomas' 'Do Not Go Gentle Into that Good Night,' Robert Frost's 'Acquainted with the Night,' Elizabeth Bishop's 'One Art' and Heaney's 'Villanelle for an Anniversary.' Etymologically and traditionally, the term 'villanelle' derives from the Italian villanella, referring to a rustic song and dance, strongly associated with the pastoral genre, and the medieaval villein, in the sense of serf, tenant and bondsman. Its standard form is a nineteen-line poem in five tercets and a conclusive quatrain in a variety of metre, normally tri- or tetrameter, with two refrains and two repetitive rhymes. Its fixed form has a bell-ringing quality, and the refrains and repetitions represent remembrance and the cycles of seasons, life and death. Its pastoral roots suit the setting of graveyard, soil and plants. There is, however, little doubt that Muldoon is, as always, also aware of the modern spelling of villain and its connotations: irreverent, self-aware and iconoclastic. Muldoon charges the rustic song of the pastoral tradition with a sense of dance and villany in a homage to parents set by the grave, in an tradition-breaking villanelle in 25 lines of seven tercets and a conclusive quatrain in mixed metre with two refrains and a very subtle chime pattern. His attention to two deceased subjects in such doubleness of meaning and form adds to the regeneration of the genre. Furthermore, Muldoon's language emphasises the sense of doubleness and ambivalence in the elegiac mood of this villanelle.

If deconstruction might be simplistically labeled as the psychoanalysis of language, the Derridean method meets its match in Muldoon's elegy. Connectivity and confrontations in the title reveal the complexity of this contorted villanelle. Alliteration and the symbiosis of flower and butterfly in milkweed and monarch unite the subjects of the title with mellifluous melody and natural harmony. This combination indicates matrimonial bliss. The two words also coalesce, as milkweed butterfly and monarch are two terms for the same insect. It is also notoriously difficult to tell one gender from the other of the monarch. However, contradictory connotations indicate conflict. The title, in its linguistic polysemy, also carves out division and difference, such as the separation of realms between plant and patriarch, vegetation under the sovereignty of an absolute ruler of state. Or perhaps that should be plant and matriarch, the two title words are gender neutral. Both words are, nevertheless, also divided against themselves: the sense of liquid nutrition and cumbersome vegetation in milk-weed suggests maternal care, wildness and parasitism, just as monarch suggests butterfly and sovereign. Consequently, the title captures simultaneously the conjugal aspects and the conflict of marriage and partnership. 
As he knelt by the grave of his mother and father the taste of dill, or tarragon he could barely tell one from the other -

filled his mouth. It seemed as if he might smother. (10)

Meditations at the tomb precipitate suffocation on the part of the mourner. Memories are too painful to bear and the integration of 'mother' in 'smother' hints more at the mother's disabling than enabling care. But 'other' half-rhymes with 'father' as well and the persona can barely distinguish between the two. A form of psychological reversion and displacement occurs as aural connections impinge themselves on the evocation of his parents. These resonances are linked with previous domestic meals and a taste for life. The binarism and polysemy of the title also structure the bifurcated bonding and contradictory semantics of 'dill, or tarragon,' plants from different parts of the world that are both used to add flavour to food. On a metaphorical level they both imply supplantation, the suppression or displacement of one thing by another existence, gender, emotions, semantics - and transformation - from seed to plant to spice - processes embedded continuously in the poem. 'Dill,' according to the Oxford English Dictionary, could also mean, among other things, a girl or wench; dole, grief and mourning; sea-weed and fool - a string of words which tends to encapsulate many of the poem's persons, and much of its situation, sorrow and transformations. That some of these usages are obsolete adds to the sense of passing and the past. 'Tarragon,' the name of another exotic plant and spice, illustrates in a single word - wittily or not - much of this volume's many motifs, traces and cryptic methods, as well as this poem's linguistic undecidability, multiple shades of grief and complex renewal. 'Tarragon' contains an assonantal echo with terra gone and sings in itself a lament to the many soils, territories and terrains that are gone, and the terra incognita to come. 'Tarragon' also ghosts with assonance the Gaelic exclamation of grief and sorrow, ochone. All merriment has disappeared, arrah gone. 'Tarragon' states explicitly in its four final letters the painful struggle, psychological conflict and verbal contest in ancient Greek drama, agon. 'Tarragon' chimes in its second half with 'again' as a phonetic involution of this poem's recollection and renewal of the deceased in the life of the living, and also of this volume's many refrains of remembrance: 'Again and again,' 'All I remember,' 'All would be swept away.' The scream of sorrow echoes in the disappearance of traditional landscape and historical grandeur: Tara gone! 'Tarragon' also records the previous sounds and transformative encounters on foreign territory of 
Muldoon's own idiom: the play on Aragon and r-g-n in 'Sushi' in Meeting the British (34-35). This plaintive poetics also reaches back to Yeats's commemoration of a glorious past and its gone heroes in 'Easter 1916,' and to Joyce's universal sorrow for all the living and all the dead in his concluding story in Dubliners: 'The Dead.' Yet 'Tarragon' keeps these old remains alive. Like new spice to traditional food, the semantic vitality, the linguistic tangibility and the formal innovations of this extended villanelle add life and renewal to old verses, to Muldoon's own elegy, to the convention of elegy and the villanelle form, to the commemoration of parents and to the memory of Patrick and Brigid Muldoon. Furthermore, 'Tarragon' connects with 'Estragon,' its French synonym and the vagabond in Beckett's Waiting for Godot that tramps about in 'Incantata,' Muldoon's elegy for Mary Farl Powers that follows on the next pages.

'Milkweed and Monarch' prolongs in its poetic ingenuity the life of two parents. Its linguistic introspection, lexical multivalence and its triumphant use of the villanelle form give contention and chaos to the deceased, and to the mourner. Muldoon's elegy is unusual in its mourning of two subjects in the same poem. Commemoration of parents in Muldoon's elegy also offers a provocative portrait of the parents. This is a very post-Freudian elegy, full of ambivalence, confusion and projection in a tradition where amour, compassion and dejection have been standard emotions. The mother tends to be presented as a conveyor of suffocation and aggression - 'He'd mistaken his mother's name, "Reagan," for "Anger"' - as much as dedication and affection. But then, again, "he could barely tell one from the other' (11). The confusion of emotion extends from familial ambivalence to erotic desire: 'Why should he be stricken / with grief, not for his mother and father, // but a woman slinking from the fur of a sea-otter / in Portland Maine, or, yes, Portland, Oregon -' (10). Erotic desire for a woman replaces Oedipal ambivalences and geographical duplicity emphasises emotional confusion. Ambivalence of maternity later extends to Mother Ireland and undefined forms of motherhood in the assonantal patternings of 'mother,' 'Irish Cliffs of Moher' and 'other' - which by its chime with 'otter' reconnects with the woman from Portland. ${ }^{28}$ 'Father' also belongs to this semiotic chain of likening and differing and this cycle of psychological, linguistic and geographical supplementation extends to the confusions of sex and identity: 'As he knelt by the grave of his mother and father / he could barely tell one

28 For a pictorial presentation of motherhood as a site of ideological struggle of family, church and motherland, see Rita Duffy, Mother Ireland, 1989.

Muldoon and Duffy have collaborated on such projects as Cloth and Thaw. Duffy's Watchtower 2 (2006) appears on the jacket image of Muldoon's One Thousand Things Worth Knowing. One of the poems in the volume has the title: 'Rita Duffy: Watchtower II' For more information on Duffy and Muldoon, see http://www.stoneyroadpress.com/books/ at-sixes-and-sevens/ and https://www.youtube.com/watch?v=2qi6peCAERM 
from the other'. The death of parents leaves an empty emotional space where the striving towards new language and novel form attempts to recover some of the loss. These continual displacements of language, form, identity and memory remove most sense of stability in the stern confrontation with the unknowable, and they personalise the excruciation of loss. Alphabetic computations, contorted composition and multiple confusions in 'Milkweed and Monarch' function to conceptualise the specifically individual in a situation that affects all mortals: death is singular and mourning unique. But both conditions are boundless and polymorphous. The emotional turmoil is expressed from a third person point of view, as if the speaking subject is striving to distance himself from the situation. The mourner removes himself from the loss that makes him lose himself in despair, a sense of slipping away of parents and the past, and of language and self, which appears again and again in intransitive idioms and mutable notions: 'For "mother" read "other,"' and 'For "feather" read "father,"' state the corrective 'Errata' in the next volume Hay (88).

'Milkweed and Monarch' tries to come to terms with death and grief in mould-breaking verses. The poem expresses anger, hate and the painfulness of death and mourning, as much as sympathy, love and grace. The poem breaches the convention of how to speak of the dead. 'Milkweed and Monarch' adds new life to the catalogue of commemoration, but as a personal elegy for his own parents these lines might sound to many readers as 'cold and passionate as the dawn' in Yeats's 'The Fisherman.'

'Incantata' expresses in excruciating evocations the loss of love, life and art in the passing away of Mary Farl Powers with considerably more heartfelt torment than 'Milkweed and Monarch.' The direct address by the speaking subject to the deceased subject resounds with desperation and lament. Muldoon's scream 'builds from pain, from misery, from a deep-seated hurt, / a monument to the human heart' (19). Mary Farl Powers (1948-1992) was one of the most important printmakers in Ireland in the second half of the twentieth century. ${ }^{29}$ Powers and Muldoon had a relationship over a number of years in the early 1980s. The spirit of their relationship might enter into many of the poems in Quoof. Her art certainly inspires Muldoon's ekphrastic poem 'Mary Farl Powers Pink Spotted Torso' $(Q, 20)$. The title is taken from one of her potato prints and the technique and non-figurative motif of Powers's image imprint themselves on Muldoon's poem. This rendition on Powers's print, a prelude to the celebratory eulogy of her, 'Incantata,' appears inaccessible, elliptic and indirect.

29 For a presentation of Powers and her art, see Brian Lalor, Ink-Stained Hands: Graphic Studio Dublin and the Origins of Fine-Art Printmaking in Ireland (Dublin: The Lilliput Press, 2011), 131-140. 
Creative processes of carving and printing shape the poem's stanzas and caesurae, which are hard to align in a single interpretation. A portrait of the artist with her instrument, a potato, in the first stanza remains isolated from images of Minnesota and fragmentary snap shots of a survivor painfully extracting himself out of a car crash in the second and third stanzas. The poem's abstraction, discontinuity and dislocation appear to be taken from Powers's print, her birthplace and possible traumatic episodes in her own life. The idea of printing, the technique of carving out of images and possibly the colour pink unite the three stanzas of the poem. Powers's print and Muldoon's poem also connect in the challenge of artistic articulation in poetry and painting, and in the sympathetic battle between the two as expressed in the proverb that a picture says more than a thousand words. As an analogy for the creative act of writing the emptiness of the white space, the clash of representation and imagination, the tugs of tradition and innovation, the concerns for form and technique, the questions of framing - the art of painting presents a plethora of similar problems to the sibling art of poetry. ${ }^{30}$

Muldoon and Powers ended their relationship after a few years. A sense of break-up and leaving informs the 1984 pamphlet The Wishbone and some of the poems in Meeting the British, for example 'The Marriage of Strongbow and

30 For some of Muldoon's other ekphrastic poems and allusions to the visual arts, see 'The Bearded Woman, by Ribera' ( $N W$, 38); 'Edward Kienholz The State Hospital' $(Q$, 21); 'Christo's,' 'Paul Klee They're Biting' and 'Salvador' ( $M T B, 21,32,49-51)$; 'Incantata' (AC, 13-29); 'The Plot,' 'A Half-Door near Cluny' $(H, 15,103) ;$ 'John Luke The Fox,' 'Anthony Green: The Second Marriage,' 'Homesickness' (MSG, 31, 32, 63-64); 'Sandro Botticelli: The Adoration of the Magi,' 'Francois Boucher: Arion on Dolphin,' (M, 15, 36); Kerry Slides (1996) with Bill Doyle; Cloth (2007) with Rita Duffy; Wayside Shrines (2009) with Keith Wilson; Plan B (2009) with Norman McBeath. Numerous other poems contain references and allusions to paintings, film and visual arts. A large number of his books have jacket designs by visual artists. For other views on the links between poetry and painting in Northern Irish poetry, see also Ruben Moi, 'Verse, Visuality and Vision: The Challenges of Ekphrasis in Ciaran Carson's Poetry', in The Crossings of Art in Ireland, ed. Ruben Moi, Brynhildur Boyce, and Charles I. Armstrong (Oxford: Peter Lang, 2014), 235-261; "Drawn by the Colour and Light": Ekphrases and Aesthetics in the Poetics of Derek Mahon,' in Beyond Ireland: Encounters across Cultures, ed. Hadda Friberg-Harnesk, Gerald Porter, and Joakim Wrethed (Oxford: Peter Lang, 2011), 181-197. For 'the visual turn' in literature and culture, see Michel Foucault's meditations upon Velázquez' in Las Meninas at the beginning of Michel Foucault, The Order of Things; an Archaeology of the Human Sciences (New York: Vintage Books, 1973); Jacques Derrida, The Truth in Painting (Chicago: University of Chicago Press, 1987); Mieke Bal, Reading 'Rembrandt' (Cambridge: Cambridge University Press, 1991); James A.W. Heffernan, Museum of Words: The Poetics of Ekphrasis from Homer to Ashbery (Chicago: University of Chicago Press, 1993); W.J.T. Mitchell, Iconology: Image, Text, Ideology (Chicago: University of Chicago Press, 1986). 
Aoife,' 'Gone,' and 'Sushi.' Powers died of cancer in 1992. 'Incantata' reveals unusually unconcealed intimate details and private memories of personal traits, primarily of Powers but also of Muldoon himself, and delineates their relationship with affection, humour and gravitas. Muldoon portrays the sangfroid of Powers in the face of a bomb-blast, her intelligence and dedication as an artist, her fatalism in denying herself much-needed medical treatment and her heroic endurance of disease, disintegration, death. He also reveals her fear of canned goods, her 'fervent eschewal of stockings and socks' (24), and her naming of Muldoon as 'Polyester' due to airs of 'too much artificiality, both as man and poet' (17). In turn, Muldoon depicts himself as trembling at the bombblast, as immature party lion and erudite conversationalist. Various verses celebrate their spiritual companionship, dining together and nights out and drives out, but also point to differences and infidelities. A more unguarded autobiographical engagement than has been customary in Muldoon's previous poetry imbues his keen with heart-rendering pain. Unsentimental and secularised, the eulogy refrains from metaphysical speculations, but ends on an apotheosis of art familiar from modernist aesthetics.

'Incantata' celebrates and commemorates Powers, their relationship and her art with resounding pain, formidable form and remarkable language. 'Incantata,' also directly inspired by Powers's art, has a much more accessible tone and recognisable form than 'Mary Farl Powers Pink Spotted Torso.' Muldoon has chosen to add variation to the eight-line stanza pattern of Yeats's 'In Memory of Major Robert Gregory' and Cowley's 'On the Death of Mr William Harvey.' The number of stanzas, forty-five, attempts to prolong by numerological representation Powers's life span of forty-four years, and to make the total number of verses come full circle, three hundred and sixty degrees, in order to encompass the endless but relentless cycle of death, and of life and the circular repetitions of sorrows. In these respects, 'Incantata,' Muldoon's neologistic title word, strikes in itself the multiple sounds and senses of an alphabetic orchestra. 'I, the primary letter, sets the speaking subject first in the swirls of sounds and significance to follow. 'In,' as a prefixal and prepositional prelude, suggests stasis in space, place, time, emotion and mind, but also process and motion from these locations to somewhere else. 'Inc', signals determination to include everything as part of a whole, to unite in one body the fate of the two lovers, the dead and the bereaved, and to form a legal corporation against the institution of metaphysical injustice - the death and separation of the living. 'Inc' is audibly inseparable from ink, the fluid that unites the two lovers in art and beyond: 'in your ink-stained hands my own hands stained with ink' (28). 'Inca,' as in an extinct civilisation of Indians, suitably refers the death of Powers back to 
Muldoon's early elegy for the last surviving member of the Yahi tribe in Calfornia in New Weather, 'The Year of the Sloes, for Ishi.' The intratextual reference bestows upon Powers the pride and probity of Ishi in the stern face of death and extinction. 'Incantata,' also intones many other moods and modes, and functions as a minimalist score for this symphony of sounds and semiotics. The title plays in and on musicology, in cantata as well as in memory. Cantata: 'Originally, a narrative in verse set to recitative, or alternate recitative and air, for a single voice, accompanied by one or more instruments; now applied to a choral work, either sacred and resembling an oratorio but shorter, or secular, as a lyric drama set to music but not intended to be acted,' explains the Oxford English Dictionary. In music, then, the neologistic title signals creative renewal as much as commemorative recollection in these heart-rending lines of pain and pathos. 'Incantata' also echoes cantos, for example Ezra Pound's, in a poem that shares with the American modernist's song the inclusion of other languages than English, a concentration on cultural artefacts, a large span of geographical and historical references, an intermittent need for encyclopedic support, and a conviction that the poetic form generates significance in and of itself. 'Cant,' the middle section of the word, sounds like thieves' patter in a poem where Muldoon steals like a magpie from the scores of music, poetry, literature, painting, the arts, as if nothing suffices to fill the abyss of loss and alienation in the aftermath of Powers's death. 'Cant' also strikes a note of hypocritical and sanctimonious talk to imply that the rites and rituals of commemoration and funerals do not always remedy the desperation and grief of the bereaved in the wake of death. The title's play on phraseology and liturgy also includes an appropriate note of failure and resignation. 'Cant' reads like misspelled 'chant.' 'Cant' also sounds like the contraction of 'cannot', in this cantpiece between life, love, death, sorrow and after-life. One can't go one. 'Incantata' sings the sounds of music, failure and impossibility. 'If music be the food of love, play on,' Duke Orsino of Illyria states in the opening verses of Shakespeare's Twelfth Night, but what if you can't? 'Tata,' the ending of the title, chants in its monosyllabic repetition the monotony of melancholy. On the other hand, the ending also signals a sense of continuance, unstopped repetition, alongside intimations of nursery expressions and a colloquial childlike idiom for parting: 'Incantata' - in the ability, or the inability, of saying goodbye. Such a childlike note integrates mollifying terms of endearment and almost comic relief to the overwhelming indignation and anger. Furthermore, the assonance of the tetrasyllabic title almost adds arias in the word, pauses of sonority and reflection in the consonantal one word alphabetic narrative of drama and pathos. 'Incantata,' in its mellifluousness, composition and form, 
screams with love for Powers, for her art, and for the time they spent together. 'Incantata' begins:

I thought of you tonight, a leanbh, lying there in your barrow colder and dumber than a fish by Francisco de Herrera, as I X-Actoed from a spud the Inca glyph for a mouth: thought of that first time I saw your pink spotted torso, distant-near as a nautilus, when you undid your portfolio, yes indeedy, and held the print of what looked like a cankered potato at arms length - your arms being longer, it seemed, than Lugh's. (13)

Sounds and rhythms in the title develop towards a crescendo throughout the poem. The first stanza reaches directly to the heart of the matter, the love for Powers and the stimulation of her prints for Muldoon's life and poem. 'Pink spotted torso' recalls Muldoon's epigenous poem to Powers in Quoof, and names one of her engravings. The words also allude to a deceased body. Powers's death and silent art are inserted into a larger picture by references to the sculptured marks of the bygone Inca culture and the art of the painter, engraver and founder of the Seville school in painting, Francisco de Herrera $\left(157^{6-1656)}\right.$. Powers's potato printing technique connects the two artists, in life, in art and in Muldoon's previous poems. Significantly, the potato yields the form of a mouth, the human organ for tender intimacy and for vocal expression. It functions as an enigmatic emblem of a silent and speechless organ of articulation, but also as a manifestation of other types of communication beyond the sign systems of sound and script. The potato mouth also appears as the auditory counterpoint to the nightmarish visions that unfold via the retinagraph in 'Madoc.' The dislocated mouth of the 'X-actoed' potato resembles strongly the disembodied mouth of Not, I, - Pas Moi - Beckett's visceral play of trauma and inarticulation of an unnamed and suffering subject in apparent metaphysical limbo. Beckett's art appears like pink spots throughout the entire poem. 'Colder and dumber than a fish,' in the clause that links Powers to Herrera, connects Muldoon's verses appositely to the dilemma of dedication and distraction in Yeats's lamentation 'All Things Can Tempt Me.' Lexicon and reference continue to connect Powers's print and Muldoon's poem to Irish culture. 'A leanbh,' Gaelic term of endearment meaning 'O Child,' signals premature death and new afterlife. Writing, etching, vocality and commemoration are tied to a mythological dimension in the mentioning of 'Lugh,' god of arts and crafts, an allusion that extends to the pre-Christian festival Lughnasa, 
inaugurated by Lugh to commemorate his foster mother, Ethniu, and to celebrate the harvest. ${ }^{31}$ 'Cankered potato,' in which 'can' spreads like contagion from Incantata, captures the cancerous attack on Powers's health, alludes to the plethora of associations with potato in Irish history and literature, and commences the linguistic disintegration to come later in the poem.

As Powers dies by cancer, stanza by stanza, the coping strategy and emotional equilibrium maintained by reference to the longevity of arts give way to inarticulate pain and linguistic apoplexy:

The fact that you were determined to cut yourself off in your prime because it was pre-determined has my eyes abrim:

I crouch with Belacqua and Lucky and Pozzo in the Acacacacademy of Anthropopopometry, trying to make sense of the 'quaquaqua' of that potato-mouth; that mouth as prim and proper as it's full of self-opprobrium, with its 'quaquaqua', with its 'Quoiquoiquoiquoiquoiquoiquoiq.' (20)

This dissolution of dirge into illinguisticity in the penultimate stanza of the first section, stanza number 23, presents disease, pain and death by disintegration of ordinary language, paroxysmic adlinguisticity and the expansion of metre. The force of repetition of insensible syllables, a failure of language in the conventional sense of dictionary words and logical communication, animates the disorderly aggression of abnormal cell growth and lethal cancer in its rapid metastasis of lexical aberration. These hacked repetitions also stutter the unstutterable and capture the cataleptic crisis of insanity, arrythmia, infarction and haemorrhage - the inabilities of language and the confusion of pathological symptoms that may take their grip upon the bereaved. These lines, in their extension of metre beyond any type of ordinary metrics and prosody, imply the infinitude of the loss, and demonstrate a drive for transcendence.

Most pertinently, metaphysical quandary, and its linguistic articulation thereof, are linked by allusion and alphabetic associations to a Beckettian and Joycean universe. Lucky and Pozzo stride straight into Muldoon's stanza from Waiting for Godot. 'There's no lack of void,' states Estragon in the same play, and later adds: 'We always find something, eh Didi, to give us the impression we

31 Brian Friel enacts the same myth in his partly autobiographical play dealing with the family and the emotional nature of individual memory in Dancing at Lughnasa (London: Faber and Faber, 1990). 
exist.' Both characters and comments entwine 'Incantata' with Beckett's plays and their panoramic futility, as does a number of other sentences in Muldoon's poem: '(remember how Krapp looks up "viduity"?),' 'His Nibs Sam Bethicket,' 'the idea I shared with Vladimir and Estrago,' 'the Thane of Calder, 'Hamm and Cloc; Nagg and Nell; Watt and Knott,' 'Watt remembering the "Krak! Krek! Krik!,' 'FitzKrapp eating his banana' (14, 15, 17, 25). Beckett's despairing examination of the human condition, his excruciating reflections upon the problems of divinity and free will, the physical disintegration in his plays and novels and their grim humor alongside the inevitability of death that his work recalls bear heavily upon Muldoon's apprehension of Powers's fate. The mnemonic device of the potato mouth - Muldoon's madeleine in remembrance of things past also imprints the verses with Beckett's discussion of voluntary and involuntary memory. ${ }^{32}$ Joyce is interpellated too, with The Dead of course, but even more Finnagans Wake via suggestions of the multilinguistic vitality of a spirit that will not surrender. The mobility of citations - Muldoon's own verses, Powers's art, Beckett and Joyce's universe - is richly suggestive: other acts ensue, the wake continues, 'Incantata' goes on.

These lines, mortilineal lines, also, in their attempt to apprehend the incomprehensibility of death, to alphabetise anguish, to formulate the inarticulate and to prolong the life of the dead in the life of the living, offer no termination and closure. Stanza twenty-three gives way to stanza twenty-four, the poem's transitional stanza of stop and continuation, death and afterlife, as another segment in the semantic chain of substitutions and displacements trying to come to terms with disease, pain, death and sorrow. 'That's all that's left of,' starts stanza twenty-four, and searches incessantly for the correct vehicle for the prepositional tenor in the stanzas to come. 'Of the great big dishes of chicken lo mein,' 'Of the bride carried over the threshold,' 'Of the Belfast school,' continue stanza after stanza in ceaseless scrutiny of relics, remnants and remembrances. The elegy moves on from the personal to the public to echo the loss of Powers on a larger scale of ruins, remnants and revenants in the consequent twenty octaves that follow:

all that's left of the hogweed and horehound and cuckoo-pint, of the eighteen soldiers dead at Warrenpoint (21) $[\ldots]$

32 See Samuel Beckett, Waiting for Godot (London: Faber and Faber, 1965 [1956]), 66, 69; The Beckett Trilogy (London: Picador, [1950-2] 1976); Collected Shorter Plays, 1st hardcover ed. (London: Faber and Faber, 1984). See also his Trilogy, Collected Shorter Plays and Proust (London,: Chatto \& Windus, 1931). 
of the remnants of Airey Neave, of the remnants of Mountbatten, (22)

$[\ldots]$

of Benjamin Britten's Lachrymae, with its gut-wrenching viola, of Vivaldi's Four Seasons, of Frankie Valli's, of Braque's great painting The Shower of Rain, of the fizzy, lemon or sherbet-green Ranus ranus plonked down in Trinity like a little Naugahyde pouffe, of eighteen soldiers dead in Oriel, (23)

Natural cycles of death and rebirth, chronicles of political murder and records of art augment and countervail the fate of Powers, and relate the distress of individual loss to individual creativity, wars, historical change and aesthetic endurance. Powers's memorable lithographs and Muldoon's poetic vitality empower an artistic embrace beyond subjectivity and death in conciliatory notes at the end of the verse cycle:

than that Lugh of the Long Arm might have found in the midst of lus na leac or lus na treatha or Frannc-lus, in the midst of eyebright, or speedwell, or tansy, an antidote, than that this Incantata

might have you look up from your plate of copper or zinc on which you've etched the row upon row of army-worms, than that might reach out, arrah, and take in your ink-stained hands my own hands stained with ink. (28)

The final lines return to the opening lines in their attention to Powers, her art and their importance for Muldoon, in verses that revert to the same myth of Lugh and include the Gaelic language. Life and commemoration are preserved by the naming of flowers, which could be both vernal and vital, or an herbarium. The plant names are given in both English and Gaelic, as if to see things through two languages, as if two languages might help to render legible the two dimensions of life and death, and the complexities of rendering sorrow and commemoration in creative language. The catalogue of flowers connects with the potato of the first stanza, but the mouth in Powers's initial print has been replaced by 'army-worms' - a grotesque image of death and renewal. These pestiferous insects are capable of skeletonising entire crops, but they also retain the idea of chrysalis and metamorphosis. Worm-like figures appear in some of Powers's etchings, for example 'Emblements' and 'Red in the Green.'33

33 Mary Farl Powers, Emblements, 1981. 39 x $48 \mathrm{~cm}$; Red in the Green, $1975.36 .5 \times 30.5 \mathrm{~cm}$. 
Their literary reference ranges from The Book of Job's 'How much less man, that is a worm? And the son of man, which is a worm? (25:6) to Beckett's The Unnamable and to Muldoon's later volume, Maggot (2010). Worms crawl as the great equaliser in the final stanza of 'Incantata.' Silent and insidious, they creep relentlessly on to complete the cycle from dust to dust. 'Arrah,' Mary's gone. Yet the dead and the mourner unite in their manual paraphernalia, the ink of etching and writing, and in the art of print and poetry that remains long after the artist is gone. Chiasmus in the final line, reminiscent of 'the snow falling faintly through the universe and faintly falling, like the descent of their last end, upon all the living and all the dead' in the ultimate line of Joyce's 'The Dead,' assigns parity of esteem to both subjects, bestows spiritual unity across the artistic and existential boundaries between them, and implies imminent reversal of fate: the mourner and the reader will some day be included in the realm of the dead.

In scope and compassion the superbly composed euphonious enchantments of 'Incantata' constitute a poetic pantheon to Powers. Private endearments, paroxysms of emotion and intense grief of personal loss are contained in the poem by repetitive rhythms and aesthetic fortitude. The strengths of love, of word print and of sound present Powers and Muldoon's unity for posterity. Frequently, the nakedly autobiographical and the painfully personal cut straight through the high artifice: Paul speaks directly to Mary. In this respect, 'Incantata' is in dialogue with the later poem 'The Grand Conversation' (MSG, 41), a markedly more impersonal, circumspect and disunited colloquy on the positions of love and partnership in the midst of larger discourses. 'Incantata,' however, overflows with agony and desperation in its elegiac effusions where 'The Grand Conversation' checks its emotions and guards its cerebral cynosure. Colourings of relinquishment, abandon and abundance in 'Incantata' recall time and time again their lost love and their sustained affinities against a panorama of war, futility and Beckettian ghosts of nihilism. Allusions, art, alphaphilia implode to fill the emotional void and the creative vacuum left by her death. These mortilineal energies are contained by a stanzaic permanence that stems from Cowley and Yeats's elegies, and by numerological patterning. A polysemantic and multilingual language conveys the complexities of death and sorrow, and enacts an indefatigable quest for a linguistic mode in which they might be communicated. Three hundred and sixty lines define a full compass circle - life cycle and aesthetic completion - and forty-five stanzas exceed the forty-four year life span of Powers by one. The first suite of twenty-four stanzas contain the beginning and end of life, lines and language and the final twenty-one octaves vociferate to extend life, lines and language beyond the end and into the new millennium, the 21st century. Muldoon's 'Incantata' 
in-un-dates the death of Powers in 1992 with personal memories and idiosyncratic language that place firmly Powers, her art and the relationship between them in the contemporary canon of commemoration.

'Yarrow,' the long good-bye to his mother, extends over the last hundred and fifty pages of this volume as an effusive elegy. Muldoon commemorates her death by cancer in 1974 with much of the same linguistic creativity and stanzaic assurance as previous elegies and birth poems in this volume. The length of time between his mother's death and these verses, as well as the length and the intricacy of the poem itself, suggest a more ambivalent relationship between mother and son than between father and son. Previous poems on his mother corroborate such a suspicion, as does the fact that the commemorative poems to his father appeared much closer in time to his death, and were, judged by Muldoon's own standards, less expansive and complex. Lines in 'Yarrow' also incorporate Kendall's 'polycentric pedigree', the introductory dedication in New Weather: 'for my Fathers and Mothers.' This later memorial poem connects more with the equivocal, bewildered and interchanging positions of 'Milkweed and Monarch' than the direct, intense and intimate confessions of 'Incantata.' Nevertheless, this elegy too belongs to the canon of contemporary commemoration in its expansive scale, epic range of reference and, perhaps most of all, in its idiosyncratic interrogation of lexical norms and digressive semantics.

'Yarrow,' like 'Quoof,' 'Madoc' and 'Incantata,' harbours multiple meanings within itself, like an oak within the acorn. Yarrow names a plant. Achillea millefolium, also called milfoil, nosebleed and kale, the strong-scented Eurasian plant of the daisy family. With its mythic connotations (Achilles used the plant for blood stanching), curative capacities and biomorphic qualities, it embodies many aspects of the poem's evolutions and preoccupations. Achillea millefolium, a fast-spreading plant of loose rosettes of leaves with no central head, configures the germination of these thousand or more verses, and reflects the nature of loss and memory: 'the line of chafers and cheeselips that overthrow as they undermine,' as grafted words in 'Third Epistle to Timothy' in the next volume Hay (101) state. These plants symbolise linguistic fertilisation, an ambivalent form of organicist poetics, the sprigs of memory, the intrusion of natural forces upon manmade culture and, more insidiously, the spreading of cancer. Yarrow, contrarily, also designates Yarrow Water on the Borders in the southeast of Scotland, a geographical reference that stirs ideas of the living stream and the passage of time, in addition to idiomatic fluency, linguistic fluidity and the flow of verse. Heraclitean philosophy of life, repetitions and change also flows with these connotations of aquacultural evanescence and eternity. Land and lake, flower and water, form oppositions in a larger universe, like life and 
death from a metaphysical perspective, like the steadfast and the fleeting in the memory of the living of the dead and the past.

Yarrow also points to past poets, primarily Wordsworth's three poems ('Yarrow Unvisited' (1803), 'Yarrow Visited' (1814), and 'Yarrow Revisited' (1838)) that chart the imagined, the actual and the repeated experience of visiting Yarrow water and flora in the Scottish-English border region. These meditations upon deferred, realised and repeated experiences of life and poetry set up a Romantic backdrop for Muldoon's poem, which its Freudian psychology, many modernist references and coruscating language scepticism tend to overturn - like Yarrow that takes over fields that are under cultivation. Muldoon's 'Yarrow' swirls self-consciously and plurally and the title is indicative of the irreconcilable linguistics and heterogeneous allusions of this synaesthetic symphony that continues the expansive Muldoonian textuality that resists paraphrases.

'Yarrow' demonstrates as much formal renewal as linguistic renovation. Elaborate sound systems and numerological contrivance compose and constrain the semiotic swirls. A poetics of sestinas and terza rima imposes awe and order on the semantic slippage and the formlessness of loss and mourning. Stanzas in terza rima are ghosted by Dantean spirits of the diceased and the otherworld and sestinas propose a template for reiterations. Typographically, these tercets render an image of an endless flow of coffins. Their set shape also invites exchanges with Heaney's sonnets in memory of his mother, 'Clearances,' and the forms and transformations of the soul, language and poetry in 'Squarings.' ${ }^{34}$ Language, form and internal references also connect 'Yarrow' with 'Incantata' and 'Milkweed and Monarch.' All three of them are elegies to two of the most important women in Muldoon's life. Both of them died from cancer. 'Yarrow' and 'Milkweed and Monarch' combine in numerous ways, for example in their biological imagery, implications of Oedipal drives, tenacious tercets and conflation of geography and women. In 'Milkweed and Monarch' the mother was confused with 'other,' 'Moher,' 'otter' and 'father,' and supplemented by the erotic recall of another woman. In 'Yarrow' the enigmatic figure $\mathrm{S}$ - configures, confronts and confuses the enabling and the moralising aspects of the protective mother. Nothing holds in 'Yarrow,' neither does the significance of $\mathrm{S}$ - , but the impetuosity and imprecations of this figure constitute some of the more sustained invectives and semiotic possibilities of this multi-faceted elegy. The mysterious S - of 'Yarrow', just like the woman in 'Milkweed and Monarch,' 'must have gone off to Portland, Oregon / rather than Portland, like Maine' (168). 'Yarrow' and 'Incantata' also converge by creative means. Both poems abound in allusions to the fine arts and popular culture. 
Muldoonian reference between them and to other poems are legion. 'Il Duce of Drumcliff' (145), i.e. Yeats, looms large in these verses too, as the master to be overcome in encounters replete with Bloomian anxiety. The pantheon in which Muldoon composes his elegy for his mother, and several others, includes numerous other dead poets, for example T.S. Eliot, Robert Frost, Louis MacNeice, Sylvia Plath. 'Yarrow' and 'Incantata' repeat again and again the lives and memories the grieving persona tries to salvage from time and oblivion. They sing in relay in their many end words, and in their overtures of artistic reference, Muldoonian self-reference against a Yeatsian backdrop.

'Yarrow' derives its rhyme and sound scheme from 'Incantata.' End words in the first stanza of 'Incantata' that continue throughout the poem - 'barrow,' 'Herrera,' 'Inca,' 'pink,' 'nautilus,' 'indeedy,' 'potato,' 'Lugh' - also find echoes with the line endings of 'Yarrow' which are constituted in the first four tercets of the poem: 'row,' 'pink,' 'us,' 'da,' 'arm,' 'wheel,' 'tarp,' 'oil,' 'rare,' 'Deo,' 'stream,' 'land' (39). These initial end sounds of the first twelve verses of 'Yarrow' reappear on seventeen occasions to introduce, structure and conclude the hundred and fifty stanzas in this sequence. In circular fashion, the rhymes and sounds of twelve terza rima sections in the envoi of 'Yarrow' hark back to its initial tercets, and to the chime words that also make up the three-hundred and sixty lines in 'Incantata.' Both poems accommodate the susurration, textual whorls, chime patterns and formal composition that characterise the language of Muldoon's poetry. This elaborate sound system, which connects 'Incantata' and 'Yarrow, continues in the combinatory linguistics of family lives in 'The Mud Room,' 'Third Epistle to Timothy,' 'The Bangle' and 'The Bangle (Slight Return)' in the next volume Hay $\left(3^{-10}, 13,97-103,109-140\right)$. Some of the sounds still linger on in 'The Braggart' (MSG, 12) and 'The Humors of Hakone' (Mag, 63). Such a conflation, continuation and slipping away of sounds and systems unite the sorrows for the dead, and suggest the slippage of memory in time. 'Yarrow,' in itself and in its extensions, presents a panorama of phonetic panache that swirls with Muldoonian neologisms and ranges and roams in registers from the accessible to the arcane to honour, to preserve and to revivify the memory of Brigid Muldoon and other foremothers.

Yarrow's many meanings inhere in the title itself: the oak was once an acorn. Linguistically, Yarrow may derive from the Celtic word garwy, meaning rough, or may share a derivation with the English place name Jarrow from Old English Gyrwum for marsh dwellers. So the title term connotes tough plant and life's hardships, possibly in an Irish context, possibly in an English context - very relevant correspondences for an elegy with a plant as a dominant metaphor written by an Irish-Anglo-American master of language. A close reading of the term Yarrow suggests several interpretations. 'Ya' designates the age of a young adult, the period of a life time from which many of these memories of 
Muldoon's mother are collected. 'Ya,' as a regional or colloquial variant of you, implies other distances and other relations than the 'I' that sets 'Incantata' going. Yarrow, the linguistic entity, contains missiles of love and death, as in $\mathrm{Cu}-$ pid's arrows and as weapons of war. Yarrow almost includes 'arrays', as if to take in all the arrangements of diverse kinds and row after row of references and incessant ingenuity that, in their totality, endeavour to fill the emotional void of the loss in the mind of the living. Fittingly also, Yarrow half-rhymes in Muldoonesque manner with sorrow.

These kinds of lexical deconstruction and atomistic hermeneutics manifest themselves conspicuously in the poem in the semiotic shifts of the figure $S-$. $\mathrm{S}$ - upsets standard alphabetic usage and draws attention to its own appearance. It appears again and again in these lines like an empty signifier in continuously new contexts. Like a slithering snake in sweaty hands, the figure ceaselessly slips away from precariously established meaning and reshapes itself incessantly. Perhaps S - represents an (auto)biographical occlusion of self or refusal to name the self or the deceased. Most critics tend to assume as much. ${ }^{35}$ While Kendall considers The Annals of Chile to be Muldoon's 'most candidly autobiographical' poem, and Wills complains that its 'wealth of cultural and autobiographical reference doesn't help to ground the poetry,' others have speculated on the signifiance of the figure $S-$. They have sought to exemplify what 'Yarrow' can release on the topics of sorrow, loss and language in non-biographical and less traditionally grounded interpretation. ${ }^{36} \mathrm{~S}-$ abounds much more in interpretational plenitude than such affirmative logics proffered by Kendall and Wills would suggest. Its undecidablity enacts the emotions of love, loss and language. Effectively, the cipher functions as the tentative 'arresting officiffer,' to employ one of the numerous neologisms from 'Yarrow' (139), to stop and start, again and again, alphabetic initialisations and semiotic swirls in the stream of sorrows and memories. The focus on a single letter of a word in a grammatical unit of larger poetic narratives draws attention to the smaller situation and almost insignificant moments that survive in memory as much as the grand occasions.

$\mathrm{S}$ - starts significance

$\mathrm{S}$ - sets the signifier before the signified

$S$ - shimmers with the secrets of syntax, semantics and shy self

$\mathrm{S}$ - shapes its own solecism

35 See for example Norfolk, 'The Abundant Braes of Yarrow'; Bolton, 'Irish Stew at the Café De Monde'; Ford, 'Little Do We Know": Review of the Annals of Chile by Paul Muldoon'; Fenella Copplestone, 'Paul Muldoon and the Exploding Sestina,' PN Review 22, no. 2 (1995), $33-36$.

36 Kendall, Paul Muldoon, 209; Wills, Reading Paul Muldoon, 12. 
S - suppurates the centrality of spelling and semantics

$\mathrm{S}$ - is if not sensuous then certainly curvaceous

$\mathrm{S}$ - slithers like a snake in the grass

$\mathrm{S}$ - chimes with slang for a specific anatomical attribute, with silly creatures and beasts of burden

S - strips silence to its initial, susurrates sonic subtleties, confounds morphological expectations, simulates and surpasses the ineffability of sadness and sorrow before death in this poem endorsed by Norfolk as 'a new kind of elegy, an elegy for the unborn and the dead alike. ${ }^{37}$

$\mathrm{S}$ - streels with self-proclaimed sluttishness against lingual purity and moral stigmatisation: 'she shrugs off her taffeta / wither-band and begs me to, like rim / her for Land's sakes; instead of 'Lord', she says 'Land' (85)

$\mathrm{S}$ - signals its own sign and infinite possibilities in signature, event, context in a volume in which typical Muldoonian neologisms occur as spontaneous diversions without rules or regulations to precipitate their own possibilities of uncertain outcome

S - introduces a lot of other 'semioticonoclasts' (79): 'The Oklamydia Kid' (49) plays on the venereal legacy of the conquest of America, on Indian tribes and Western fictions in a quasi-confessional poem where the persona's memories of Irish childhood are already infested with Americana, and the young gun hooks up with $S$ - who comes to host 'sores not unlike those of herp- / es or Chlamydia' (161). 'Elizabloodybeth' (84) inseminates the virginity and violence of courtly power play, plantation politics and the Irish Rising. 'Catlick' (136) configures linguistic equivocation religious denomination and sexual felinity. 'Labiaba- / ring' (150) exhibits Babylonian babble and pierced lips. Of both kinds. More often than not unscrupulous semiosis is, significantly, tied to sexual variance: lip service and acts of invagination. Sexuality implies the fertility, fatality and reckless risks of linguistic experimentation: in The Annals of Chile such methods might seem repellent and exhaustive, but they indubitably intensify and augment hermeneutic alternatives, like quoofing around $\mathrm{S}$ - celebrates sensuous gratification and sex: 'and S - and I, like, outparamoured the Turk' (148)

S - soars sky-high with Dionysian revelry and Nietzschean vitalism

$\mathrm{S}$ - contrasts and conflates a number of deceased women in the book: the mother, Mary Farl Powers, Maud Gonne (Mise Eire), Myrna Loy and others $\mathrm{S}$ - stretches to include father figures in the feminine catalogue $\mathrm{S}$ - slinks in and out of the many positions of subject and object, serves as subjugator of semantic certainty as much as a supplier of coded significance,

Norfolk, 'The Abundant Braes of Yarrow,' 33. 
slides with sameness, semblance and alterity in identitarian questions. S counterpoints the mother, but the two also blend. S - seduces the persona into sex, drugs and dissipation; the mother exercises maternal care and protection: the two figures suggest images of Mother Ireland, Mother Mary, and sometimes they switch roles. Although the mother at times seems a stereotypical Jewish mother, she is closely associated with the traditional values of purity and religion in Northern Ireland: 'For your body is a temple' (68), 'For Satan finds some mischief still for idle hands' (90). S - stages melodramatically revolutionary republicanism, circulates the apocalyptic gospel of Dark Rosaleen, summates other heroines: 'Throughout all this she wears some kind of ski-hood or - mask' (86), 'her face in the freeze frame was not unlike Maud Gonne's (131), 'from Aghalane to Artigarvan to Articlave the Erne and the Foyle and the Bann must run red' (109). (At points S - and the mother are almost confused and they both suffer excruciating and drug-induced deaths, for entirely different reasons: heroine addiction and cancer. Contradictory and conflated, the two feminine figures subvert stable processes of identification and development.)

$\mathrm{S}$ - and the mother record the intensity and complexity of transient periods in the life and history of Northern/Ireland

$S$ - sums up several of the stances in critical approaches to Muldoon's poetry

S - supports the poetry of Pablo Neruda in advocacy of politically committed poetry in a critically still unexplored template for The Annals of Chile: "Take Neruda," S - volunteered, "a poet who dirtied his hands / like a bona fide minstrel boy / gone to the wars in Tacna-Arica"' (156)

$\mathrm{S}$ - scolds the persona, possibly a partial self-portrait of Muldoon, as much as other poets in Northern Ireland, with scathing scatological satire: 'You're just another Sir Pertinax / MacSychophant, / brown-nosing some Brit who's sitting on your face / and thinking it's, like, really cool' (163). If Muldoon is sanctioned for his even-handedness in his treatment of the Northern/Irish controversies, such impartiality is equaled by his sense of equivocation towards the demands of communal commitment in a partitioned society. Such accusations, selfgenerated, justified or not, stem from entrenched politico-theoretical priorities that ignore many aspects of Muldoon's poetry, or disapprove of its tendencies to criticise all sides, and exhibit a bias in favour of a homogenous type of poetic idiom. These accusations of self-indulgent solipsism also bridle at Muldoon's escape to luxurious academic positions in the United States. Northern Irish matters appear less prominent in Muldoon's middle oeuvre, and although these volumes attend with scepticism to ideological and historical formations of the U.S., they tend to be less vitriolic in their treatment of contemporary 
American issues than other parts of his poetry are of issues in Northern Ireland. In effect $\mathrm{S}$ - operates as a dissenting voice in respect to special stances in poetics, not only of political commitment, but also of intense emotionalism:

To find a pugilist-poet who'd tap his own prostate gland for the piss-and-vinegar ink in which he'd dash off a couplet of 'sparrow-

songs', then jump headfirst into her fine how-d'-ye-do heedless of whether she'd used a deodorant, that was $\mathrm{S}$ - 's ideal (65)

Poet-boxer-art critic-dadaist Arthur Craven ('Artilutteur Ecrivain,' 'Agravain of the Hard Hand,' 'Agravyn à la Dyre Mayn,' 'Agravidos,'), Edith Piaf and Sylvia Plath belong to her poetic pantheon of which the persona is sceptical. S sublimates the mortilineal school of suicides that infested parts of the modernist poetics and culminated in the fate of Plath and in Alvarez's call for the forces of disintegration and his meditations upon suicide. ${ }^{38}$

$\mathrm{S}$ - slits itself short, $\mathrm{S}$ - spells its own suicide, $\mathrm{S}$-'s cessation is inscribed in the tumultuous contexts of pop lyrics by Beatles, sensational murder by Charles Manson and the biblical prophecies of Belshazzars's feast: 'S - wrote 'Helter-skelter' / in her own blood on the wall, she'd hidden a razor in her scrubs' (184). Symbolic and savage, the act of suicide counteracts maternal selfsacrifice, echoes the tragic fate of many modernist poets and artists and the self-depredation of rock and roll mythology, and proclaims the transitions of eras. Plath's tragic act of suicide strengthens the forces of life in the volume: the alternatives of suicide and sacrifice augment the individual's responsibility for life. On the other hand, was that only an unsuccessful suicide attempt as S appears again and again after acts of termination and words of farewell?

$38 \quad$ Albert Camus's The Myth of Sisyphus is the locus classicus for the meditation upon existentialist suicide in the modernist era. Alvarez requests disturbed and darkened poetics in 'The New Poetry or Beyond the Gentility Principle,' the introduction to his anthology The New Poetry (Harmondsworth: Penguin Books, 1962). He also conducts a cultural analysis of suicide in The Savage God: A Study of Suicide (London: Weidenfeld and Nicolson, 1971). Muldoon's cerebral poetry tends to side with James Fenton's ironic retort to (Alvarez's) self-deprivative emotionalism: 'He tells you, in the sombrest notes, / If poets want to get their oats / The first step is to slit their throats. / The way to divide / The sheep of poetry from the goats / Is suicide.' Morrison and Motion, The Penguin Book of Contemporary British Poetry, 13 . 
$\mathrm{S}$ - stains the verses with the iniquity and sin that many of a religious disposition will detect in these scenes

$\mathrm{S}$ - solicits censorial sanctions

$\mathrm{S}$ - suggests, perhaps, the solid spanking, which the 'perennial spoofer of false piety' might deserve ${ }^{39}$

$\mathrm{S}$ - certainly slams a person in the poem that sounds very much like Paul Muldoon: 'Thing is, a Phóil, your head's so far up your own fat butt / you've pretty much disappeared' (163) - the 'disappearing up his own bum' of Quoof (47)

$\mathrm{S}$ - sags and slumps with the squalor and seediness of subversive and subverted self-esteem

$\mathrm{S}$ - smacks of the stuff that sends the eponymous female figure in 'Yarrow' to the summits of sprightliness and to the slumps of self-depredation $\mathrm{S}$ - slaughters, in its solitude and self-abnegation, Soroptimist International $\mathrm{S}$ - signifies shamelessness in a collection that is suffused with Oedipal desire, salacious sex and insatiable textuality

$\mathrm{S}$ - surveys the catalogue of scandalous strumpets and strong and superior feminine figures in Muldoon's collections

S - surprises, shocks, sucks, suppurates and supplies 'The More a Man Has the More a Man Wants' with a feminine counterpart

$\mathrm{S}$ - sallies forth on the seas of semiosis and the geotemporal and imaginative journeys that recall the circles and cycles of identifications and circumnavigations of travels in Why Brownlee Left, in particular 'Immram'

S - signals the alphabetisation of 'The Plot' in Hay and '@' in Maggot and shows the abced-minded Muldoonian methods

$\mathrm{S}$ - summarises the slips and slides, curves and cuts of 'Yarrow'

$\mathrm{S}$ - satirises and sexualises, much to the persona's chagrin, the saccharined lyricism of feminine voices in Yeats's 'Hound Voice' and the rose symbolism of 'Il Duce of Drumcliff' (145) in deliberate misprision and misnaming to cut into the psychoanalytical depths of the Nobel Laureate's aristocratic mind and imagery, to point to fascist tendencies in his thinking, to chart the changes of feminist opprobrium and the figuring of the feminine in poetry: 'How dare you suggest that this "far-off, most secret /, and inviolate rose" is a cunt: / how dare you misread // his line about how they "all gave tongue;" / how dare you suggest that Il Duce of Drumcliff / meant that "Diana Vernon" and Maud Gonne gave good head' (145) 
S - synthesises, splits and spools Muldoon's own textual ambivalences, and sorts out Yeats's legacy by keeping the Nobel Laureate's idiom current in continuous attempts of devaluation

S - scrutinises how spiritual sprightliness might vie with, or stem from, selfdestruction, a template that runs in Muldoon's writing from the self-destructive forces in 'Wind and Tree' in New Weather to the abjection and seditious assaults on idealism in 'Madoc' (Mad, 15-261) and the ironic comments on old pieties in 'The Old Country' $(H L, 38-46)$

$\mathrm{S}$ - speculates in slang, Spanish, solecism and unsavory sexuality to unsettle sartorial eloquence, linguistic certainty, moral taste: 'I got from under S -'s cheese-cloth skirt / where what I'd taken for a nutmeg-clove // tasted now of monk's-hood, or anconite: / "No tengo," the salamander fumed, "no tengo / nas que dar te;" and I saw red, red, red, red, red' (164)

S - samples and solders the visuality of sexual attributes and the sound symbolism of sudden death: 'Sharp was her end as the scimitar of Salah-ed-din' (176)

S - swivels the many cities from 'Seville' (122), 'Skagerrak' (138) and 'South Tyrone' (88) 'to San Diego by way of Santa Cruz' (135), to survey in geographical terms the boundless topology of mourning $\mathrm{S}$ - stands for all the spices, substances, plants, vegetables, fruits and flowers that highlight the absence of chilli, that overlap in meaning with each other, with people, politics and poisons, and that introduce to Muldoon's corpus of mourning questions of tact and taste: anconite, anise, arum, cabbage, carrageen, carrots, dandelion, green shoot, hay, hogweed, horehound, jacaranda, jasmine, kale, kief, monk's-hood, nosegay, nutmeg, olive, parsnips, peyote, poppy, ravensara, salt, samphire, satsuma, seaweed, spinach, swede, tonka, vinegar $\mathrm{S}$ - swirls with the solos, sounds, symphonic rock music and voiceless electronics of Beatles, Eric Clapton, Jimi Hendrix, 'Jean Michel Jarre's loathsome hocus-pokery' and 'the loathsome Mike Oldfield' (86) and U2 to exemplify Muldoonian sonification and the importance of popular music to his poetry that amplifies in his rock and all poetry suite 'Sleeve Notes' $(H 29-52)$; his 'Bob Dylan at Princeton,' November 200o' (HL 24); his rock lyrics sung by Warren Zevon and Bruce Sprigsteen, 'Macgillycuddy's Reeks' and 'My Ride's Here;' his elegy for Warren Zevon, 'Sillyhow Stride: In Memory of Warren Zevon' (HL, 95107) and his many song lyrics for his readers in general and in his own bands Rackett, Wayside Shrines and Rogue Oliphant: General Admission, Songs and Sonnets, The Word on the Street and Saide and the Sadists.

$\mathrm{S}$ - salutes the artists, heroes, writers who vitalise this elegy: Charlemagne, Cicero, Salah-ed-din, Schwitters, Shakespeare, Shane, St John and Zorro to complement the personal eulogy with art from all walks of life 
S - solicits the many names of ships and submarines: Caledonia, The Golden Hind, Nautilus, The Pequod, galley and trireme to add a maritime register to Muldoon's botanical, ornithological and neologistic lexicological specialities, and, possibly, to launch a broadside in retaliation to Carey's charges of a poetry 'packed to the gunwales with higher education'40

$\mathrm{S}$ - sieves suitably into Muldoonian spoofs, skits and shenanigans

$\mathrm{S}$ - points to the many directions of South

$\mathrm{S}$ - issues a summons to the sordidness and semblances of liberty in Saorstát and the states of America

S - simmers with the seditious spirit of Shan van Vocht, splays out the sacred and secular dualities of Sheela-na-gig, shunts the female vindication in Merriman's The Midnight Court, screens the shock of the shifts in Synge's Playboy of the Western World and salutes strong women with similarities to those in Synge's Riders to the Sea

$\mathrm{S}$ - secures the semiotic methods, surreal imagination and subversive stances of Muldoon's alphabetic cynosure and synaesthetic transtextualities

S - sucks 'the "semen" out of "semantics," to cite the antics of '[Carnap]' in Madoc ([222])

S - stings with 'the semioticonoclast' (79) of 'Yarrow'

$\mathrm{S}$ - splinters stabilities of all kinds: writing and referentiality, life and death, and unsettles assured distinctions

$\mathrm{S}$ - searches ceaselessly for its own continuance and ending

$\mathrm{S}$ - smarts with all that is not said, not spoken, not written: all that remains inside and outside the letter, 'Yarrow,' The Annals of Chile, language, life, death $\mathrm{S}$-, in 'Yarrow,' results not from an accidental choice of letter. Its transfigurality surpasses concepts of initials, identity, anonymity and referentiality. This semiotic technique probes the processes of language, love, birth, death and mourning as the single letter initiates pluralities of the unknown. The multiple meanings of S - augment the notion of unknowingness in the stern face of death, the emotional flux in its aftermath, and the artistic apprehension of death and grief in language.

$\mathrm{S}$-, on occasions, suggests several different people. Naming belongs to the first acts of mental appropriation (in the biblical sense, family ceremonies, pet names) and cannot avoid the problematics of paronomasia: absence, identifications, alterity. A name frequently serves to call into presence the identity of someone removed in time or space, or someone who might be fictitious or of uncertain origins in the first place. Appellations foster contact and communication; identities are, however often confused in evocations of individuals. If

$40 \quad$ Carey, 'The Stain of Words,' 56. 
these confusions of the name to some degree inhere in language, they become pierced by notes of mourning and lamentation. The individual to whom the name appeals is irrevocably absent. The dead recalls to the living other beloved family and friends, and other people who have passed away. Questions remain of how well the mourners actually knew the deceased, their relations in life, and what might have been different. Funeral ceremonies mark the ineluctable end of a person's life on earth, but the name survives the named. In its truncations of ordinary morphology, communication and logic $S$ - exhibits the inadequacies, absurdities and impossibilities in writing and speaking before the dead. Significantly, S - figures its own unspeakability, but also the desperate insistence to pay tribute to the dead, and not be subdued into silence. The single letter signals the will to say something, initiates undefined utterances with no end, and illustrates the disturbances of writing of, to, and in the words of the dead.

Perturbations of presenting the dead inhere in 'Yarrow. S -, the mother, the father, the other and all the dead in the poem are addressed with a certain frankness and reproach as much as with care and compassion. Transgressions of taste and tact challenge ordinary decorum of ceremony and language, and of standard decency in acts of remembering the dead. Such renunciations of conventional pathos might appear spiteful and vindictive, but they also account for the anger before death, and fortify the relations of love that are now separated by the grave. Conflict and differences are not excluded from love and enduring relationships. Animosity frequently structures the possibilities of love: love remains a fundamental phenomenon of family, friendship and community that retains the capacity to endure, to transform and to outlive enmity and fractiousness. 'Even amidst fierce flames, the expiapiaratory rush / of poppies in July, October poppies' (58), runs a line in the elegy. Encounters with death, the dying and the dead precipitate perplexities of conscience, expiation of religious orthodoxy and psychological trauma that are well known in Irish literature. 'Yarrow' writes a fine line between confession and pride, and between the deep depths of desperation, acts of apostasy and states of listless destitution. The anguished supplication for penitence and delivery runs, among other texts, from the Book of Psalms, Augustine's Confessions and Wilde's De Profundis to the prayers for the dead and funeral rites of the church. In the dream play of the Circe sequence in Ulysses, Stephen defends his recusancy against his mother's ghost: 'They say I killed you, mother. He offended your memory. Cancer did it, not I. Destiny. ${ }^{\prime 1}$ The evanescence of emotions, memory

41 James Joyce, Ulysses (Harmondsworth: Penguin, [1922] 1986), 474. 
and words in Krapp's Last Tape, includes the musings on 'viduity' and the recollections of withdrawing from the mother's death bed. 'Yarrow' constitutes a secular catalogue of the dead that resists apriorities of religious condemnation and piety. Similarly, the uproarious language and abrasive attitude frequently upset conventional ceremony and commemoration. Linguistic calcification, formal petrifaction and traditional memorilisation confine the singularity of the dead and the mourner, and the welter of uncontainable emotions within set forms and the inerasableness of the said. One of this poem's many memorable qualities lies in its incessant quest for words, forms, references and sounds that might grasp some fragments of the death and devastation that established language and previous poetics fail to articulate.

Lest we forget. Sophocles' Antigone and Shakespeare's Julius Caesar are only two reminders from world literature that enact how speaking before death and the dead can hardly ever be extrapolated from a public and political context. In Ireland and Northern Ireland rites of the dead do not merely appear in an already defined political and social context; they also serve to exercise powers that change these contexts. Eibhlin Dubh O' Connel's 'Lament for Art O'Leary,' Robert Emmet's speech from the dock, Patrick Pearse's oration at O'Donovan Rossa's graveside in 1915, Yeats's 'Easter 1916,' Gerry Adams's tribute to Bobby Sands, Michael Stone's attack on the mourners of the Gibraltar victims in the Milltown Cemetery and in the M C the police surveillance of paramilitary funeral parades, Remembrance Day and all the annals of the Troubles victims in books, journals, magazines and newspapers amply demonstrate that words spoken at the graveside or written tributes to the dead are often explosive in an Irish context. Remembrance frequently instigates conflict, not conciliation. Cortèges and cemeteries are arenas of contention and violent confrontation. 'Yarrow' incorporates the troubled heritage of commemorative ceremony in a divided community in the mother's account of the United Irishmen, constitutional politicians and revolutionary rebels in the Republican tradition:

the legacy of Arthur Griffin'

(she meant Griffith) 'and Emmet and Wolfe Tone

is lost, completely lost

on our loanin'-end ideologues,

while the legacy of Connolly and, God help us, Pearse

is the latest pell-mell in Pall Mall.' (165)

'Yarrow' crosses into the complex politics of mourning, but dwells more on the private than the public dimension. The historical conflict and political situation 
of Northern Ireland appear steadfastly in Muldoon's poetry, but the elegies in The Annals of Chile tend to be overburdened by personal matters. Artistic attention to subjects that cannot respond - The Annals of Chile - raises questions of taste, tact and responsibility; the many indelicacies of 'Yarrow' heighten these considerations. Questions of exploitation surround these elegies, as they do the Catch 22 of embracing or eschewing the troubles of life and death in the poetics of Northern/Ireland. Language is always defiled, impure and contaminated and recourse to language cannot spare its subjects such imperfections. No subject is ever pristine and pure. 'Yarrow' does not conceal these unavoidable disenchantments.

In its rare, possibly singular, poetic contrivance, the novelty of $S-$, in its uncontrollability and vitality, memorably serves to mark the deaths commemorated in these annals. If death precipitates a state of change and shock in which the deceased and the mourner are no longer themselves, 'Yarrow' registers such ineffable, ultimate, terminal inevitability by altering the very media in which such deprivation is registered: language, elegies, eulogies. 'Yarrow' ends on notes of irretrievability and placelessness:

that I've either forgotten or disavowed;

it has to do with a trireme, laden with ravensara,

that was lost with all hands between Ireland and Montevideo. (189)

The many geo-temporal circuits of memory and mourning, from life in Armagh to the designation of South America promised by the collection's title, disappear at an unspecified time and place. Memories of Muldoon's mother, the stride and slips of $S$-, all the multifarious commemorations have already sunk without trace. The sunken ship becomes symbolic of the poem's hidden meanings and the impossibility of arriving at a safe harbor for which it searches emotionally and poetically. The accumulations of the cycle's chimes in the final envoi refer the poem's ending back to the many preceding sounds and circles. This failure of arrival, the sunken ship and the linguistic recircularity, tends to deny recovery and finality: sorrow remains continuously. 'Yarrow' enacts in its overflowing language the loss and bereavement of Brigid Muldoon, and of lost family and friends in both bio- and bibliographical terms. The poem also refuses to participate in recriminatory condemnation or redemption before the dead, and conceptualises in riveted language a life of living with death and the dead.

The Annals of Chile makes use of novel language to write anew the profound moments in human existence: birth, death, art. Such existence-and life-altering events instigate emotions of and meditations upon felicity, fatality and 
transformation, and the challenge, particularly to writers, of how these phenomena might be articulated in written form. Muldoon's translation of Ovid's Metamorphoses in the first poem introduces these themes that appear from $\mathrm{A}$ to $\mathrm{Z}$ in this volume. All of the poems contain in their creative and coded language some aspects of the mysteries of language, of cradle and of crypt. Vitalogues - 'The Sonogram,' The Footling,' The Birth' - and narrathanotografies - 'Milkweed and Monarch,' 'Incantata,' 'Yarrow' - form a syzygy of vitality and mortality in the volume. Mysticism in these poems does not indulge in metaphysical speculations upon the fates beyond earthly existence, as the volume focuses on the apprehensions of miracles of birth and sorrows of death among the living. Alphabetic dis-solutions and formal organisation attempt to conceptualise anew the mysteries of life and death for the living, and to mark their subjects with individuality and singularity. Muldoon's birth poems might be some of the first celebrations by a man of a daughter's coming into being and their alphabetic energies, neologistic generation, sonogrammatic scanning and sonnetic development grapple with the inexplicability of the event, and the desire to register her uniqueness in language and form. Muldoon's mourning of death becomes extremely memorable for its intellectual acknowledgement and linguistic enactment of forgetting. The elegiac imperative to remember records incessantly the transformations of language, of fugitive memory and of corrosion of time. Life and death in these poems function not only as personal events that merit poetic scrutiny, they also figure the inscrutable processes of language and poetry: linguistic engendering and atrophy, poetic procreativity and canonical decomposition. Celebrations of birth exude affirmative powers in The Annals of Chile, as do the elegies in their sangfroid stoicism and their exhibition of the many alternatives - sacrifice, suicide, solipsism - that enlarge and encroach upon the choices of life. The Annals of Chile marks a publication in Muldoon's oeuvre, and in the canon of commemoration, in which generative alphabetisation and formal renewal pay tribute to the newborn and the deceased of his own family. The volume remains cryptic in its exposure of how these phenomena - birth, death, art - do not have a core of essence that can be accessed with determination and finality. Moreover, a linguistic medium that is always indeterminate and relational affords no stable definitions of the mysteries of human origins and life-span, or the vestiges of their presence, for those who mourn a loved one. The Annals of Chile discloses the surreptitious comforts of conventional communication and traditional rites before the incomprehensible conditions of existence, and it maintains and insists upont the mysteriousness of language, nativity and mortality by denying explanation and solutions. The consolation to the writer, the reader 
and the bereaved remains in Muldoon's successful attempts to articulate again the frequently unspeakable joys and unutterable sorrows in a language that offers as much refraction and restraint as completion and reference. Events of quotidian life and radically darkened thematic concerns are defamilirised and rendered in deconstructive language. 